\title{
The allure of technology: How France and California promoted electric and hybrid vehicles to reduce urban air pollution
}

\author{
David Calef · Robert Goble
}

Received: 15 May 2005 / Accepted: 19 July 2006 / Published online: 1 March 2007

(C) Springer Science + Business Media B.V. 2007

\begin{abstract}
All advanced industrialized societies face the problem of air pollution produced by motor vehicles. In spite of striking improvements in internal combustion engine technology, air pollution in most urban areas is still measured at levels determined to be harmful to human health. Throughout the 1990s and beyond, California and France both chose to improve air quality by means of technological innovation, adopting legislation that promoted clean vehicles, prominently among them, electric vehicles (EVs). In California, policymakers chose a technology-forcing approach, setting ambitious goals (e.g., zero emission vehicles), establishing strict deadlines and issuing penalties for non-compliance. The policy process in California called for substantial participation from the public, the media, the academic community and the interest groups affected by the regulation. The automobile and oil industries bitterly contested the regulation, in public and in the courts. In contrast, in France the policy process was non-adversarial, with minimal public participation and negligible debate in academic circles. We argue that California's stringent regulation spurred the development of innovative hybrid and fuel cell vehicles more effectively than the French approach. However, in spite of the differences, both California and France have been unable to put a substantial number of EVs on the road. Our comparison offers some broad lessons about how policy developments within a culture influence both the development of technology and the impact of humans on the environment.
\end{abstract}

Keywords Environmental policy · Technology policy · Policy styles · Air pollution · Sustainable transport . Electric and hybrid vehicles

D. Calef $(\bowtie)$

Visiting Fellow, Fondazione Eni Enrico Mattei, Corso Magenta, 6320123 Milan, Italy e-mail: dacalef@yahoo.com

Current address

D. Calef

Via Carlo Alberto, 24, 00185 Rome, Italy

R. Goble

Research Professor, Environmental Science and Policy Department, Clark University, 950 Main Street, Worcester, MA 01610 


\section{Introduction}

In an effort to reduce air pollution in Los Angeles and other metropolitan areas in the state of California, the California Air Resources Board (CARB) ${ }^{1}$ adopted in September 1990 a plan to encourage the development and use of zero emission vehicles (ZEVs). At the time only battery-powered electric vehicles (EVs) qualified as ZEVs while other potential ZEV technologies, such as fuel cells and flywheels, were far from being commercially viable. The ZEV mandate was just one component of a multi-pronged attack on pollution, but it was the one that attracted the most attention throughout the following decade. ${ }^{2}$

The regulation created in California is an example of technology-forcing; it required the regulated industry to produce and sell efficient EVs, within a set period of time, even though the technology was not fully developed when the regulations were created. As in the case of the 1970 Clean Air Act Amendments (CAAA) that compelled the auto industry to introduce catalytic converters, the major automakers, the oil industry as well as several policy analysts bitterly contested the ZEV regulation. Indeed the mandated development of EVs triggered a controversy about the merits of the new technology that engaged substantial public participation in California and in the rest of the country. This is not surprising. To a far greater degree than people in other industrialized countries, Americans often vigorously debate technological issues, whether concerning electric cars, information technologies, antidepressant drugs (Prozac), public health measures (fluoridation) or national defense systems (Strategic Defense Initiative). And the controversies that typically accompany public discourse on any of these technologies have usually intensified each time the new technology was regulated by the federal government or, as in the case of the ZEV mandate, by a state agency. ${ }^{3}$

Over the same time period, starting in 1992, and throughout the 1990s, the French government designed policies and passed legislation to encourage the deployment of EVs as a means to improve air quality. But in France the process of creating regulations designed to promote EVs was devoid of conflict between government and industry and the role of interest groups was much more restrained than was the case in the United States. Indeed one would have been hard pressed to find any debate at all about EVs in France.

Our study contrasts the EV policies adopted in California and France, the relationships between industry and government, societal attitudes toward technology and the role of interest groups. We explore the distinctive features of US regulation of air pollution in the transportation sector and describe how and why Americans have paid heightened attention to electric cars, show how polarized the debate about EVs was in the United States, and contrast that debate with the collegial atmosphere that characterized the emergence of EVs in France. We compare what has happened to date in the two settings with respect to EV technology and the effects on urban air pollution. Our objective is to extract from the comparison some broad lessons about how policy developments within a culture influence both technology development and human impacts on the environment.

\footnotetext{
${ }^{1}$ Established in 1967 to promote and protect public health, the CARB has focused on three main objectives: (1) attain and maintain air quality throughout the state; (2) conduct research into the causes of and solutions to air pollution; and (3) attack serious environmental problems caused by motor vehicles.

${ }^{2}$ In the United States, between 1992 and 2000, academic and technical literature as well as the national print media devoted a great deal of attention to the ZEV mandate. Throughout those years, think tanks, university research teams, newspapers, large-circulation magazines and business organizations produced essays, reports, editorials, cover stories and ads that focused on the zero emission component of a broader pollution-reduction strategy.

${ }^{3}$ For an analysis of the conflicts surrounding new technologies in the US see Mazur, 1981 and Nelkin, 1992. 


\section{Policy styles: An overview}

There is a tradition of cross-national studies which over the last 25 years has tried to make sense of the variety of environmental, risk and consumer regulations adopted in various industrialized nations (Ashford et al., 1982; Brickman et al., 1985; Badaracco, 1985; Kelman, 1980; Lundqvist, 1980; Vogel, 1986,2003; Wilson, 1985). The specific subject of these comparative studies ranges from air and water quality control to chemicals regulation and occupational health hazards. Although in the majority of these cases the aim of the regulatory actions in France, Germany, Sweden, the United Kingdom and the United States was similar, the design and the implementation of the policies differed greatly. In particular, all the analyses emphasized how sharply the American policymaking environment differed from its European counterparts.

Starting in the early 1980's, analysts who tried to explain why environmental and risk regulations varied so much among industrialized nations used the concept of "policy style" introduced by (Richardson, 1982). In his work, Richardson argued that nation states develop "standard operating procedures" for making and implementing policies and those different styles of policy are influenced by deep values rooted in societies. Furthermore, he formulated a basic typology of policy styles based on two main features of policymaking: (1) the government's approach to problem-solving, which ranges from anticipatory (or active) to reactive, and (2) the government's relationship with other actors involved in the policy process. This definition translated into a matrix composed of four hybrid styles: anticipatory-consensual, anticipatory-impositional, reactive-consensual and reactive-impositional. In the years since Richardson and his collaborators proposed the matrix, several analysts have enriched the policy style canvas with additional typologies (van Waarden, 1995.) Analysts often found that even when outcomes were similar, policy patterns of different nations were quite diverse. The concept of "national styles of regulation," introduced by Vogel in 1986, became an important framework for analyzing policy issues (Vogel, 1986). More recently, the question of "policy convergence," that is, the trend of policy alignments brought by forces such as economic integration treaties, international legal constraints and the ongoing transfer of technological and scientific expertise, has emerged. Since the last twenty years have witnessed a sharp reduction of the barriers to economic, political and cultural exchange, it seems timely to ask whether this trend has eroded governments' capacity to design distinctive national policies. In our study we examine in one detailed case whether these recent globalization trends were able to offset countervailing forces such as distinctive national cultures, legacies of past policies and specific domestic circumstances. We address the following questions: Regarding clean air policies affecting passenger cars, is it still possible to identify clearly national policy styles in California and France and, if so, to what extent do these affect policies and policy outcomes?

\section{Air pollution in California and in France}

Over the past 33 years, California has distinguished itself for passing the most innovative and advanced legislation to control and reduce air pollution produced in the transportation sector, mainly because the Los Angeles basin and other metropolitan areas in the state have suffered the worst air quality in the country. ${ }^{4}$

\footnotetext{
${ }^{4}$ Los Angeles and its suburbs lie in a basin surrounded by a ring of mountains to the east and onshore winds from the west, both of which serve to trap the pollution. Strong sunlight activity produces the photochemical reactions that lead to smog formation.
} 
Table 1 The rise in population, registered vehicles, and VMT in California: 1960-2004

\begin{tabular}{llll}
\hline Year & Population (Million) & Registered vehicles (Million) & Vehicle miles travelled (Billion) \\
\hline 1960 & 16 & 8 & 71 \\
1980 & 24 & 17 & 155 \\
2000 & 33.4 & 23.4 & 306.3 \\
2003 & 36.4 & 25.2 & 330.7 \\
\hline
\end{tabular}

Sources: Caltrans, 2001, 2004; U.S. Census Bureau, 2005; and U.S. Federal Highway Administration (FHWA), 2003

\section{Ozone Air Quality Trends: 1976-2000}

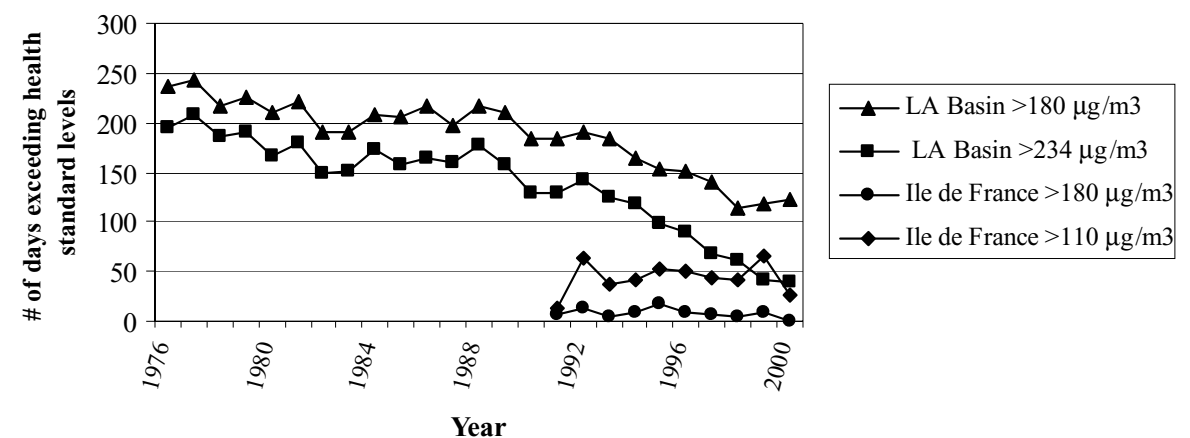

Fig. 1 Ozone air quality violations in Los Angeles and Paris between 1976 and 2000. Sources: Airparif, 2003; and South Coast Air Quality Management District (SCAQMD), 2003

Nowadays, in most metropolitan areas, cars and trucks are the major source of air pollution. This holds true in California, where on-road mobile sources are responsible for $51 \%$ of nitrogen oxides (NOx) and 33\% of reactive organic gases (ROG) both ozone precursors (CARB, 2005). ${ }^{5}$ Over the last five decades, automobile use has increased steadily in California as well as in the rest of the United States (California Department of Transportation (Caltrans), 2004) and in every other industrialized country (European Commission, 2005; Schipper, 1995). Table 1 shows the progressive growth in population in California, paralleled by the rise in the number of registered vehicles and number of vehicle miles travelled (VMT).

These trends show no sign of abating soon: as measured by VMT, automobile use is forecasted to increase for the foreseeable future (CARB, 2005). Despite the steady rise of population and VMT in the Los Angeles area, air quality has improved substantially, as shown by the trend in Figure 1. (ozone trends in the Basin Area and the Ile-de-France). Nonetheless, there are still numerous days when ozone levels remain higher than the standard judged safe by the state.

Thus progress in air quality achieved by means of strict air pollution control regulation and ever-improving emission control technology has been insufficient. The air of the Los Angeles Basin remains extremely unhealthy and the state of California dominates the U.S. smog "top ten," boasting five areas with the highest ground level ozone levels and eight areas

\footnotetext{
${ }^{5}$ In 1990 , when the ZEV mandate was proposed, on-road mobile sources accounted for $55 \%$ of $\mathrm{NO}_{x}$ emissions and $47 \%$ of ROG emissions (CARB, 2005). 
Table 2 Data on road transportation for France, the USA and California in 2002*

\begin{tabular}{lcclll}
\hline & $\begin{array}{l}\text { Population } \\
\text { (million) }\end{array}$ & $\begin{array}{l}\text { \# of vehicles } \\
\text { (million) }\end{array}$ & $\begin{array}{l}\text { Public transport } \\
\text { ps-km (billion) }\end{array}$ & $\begin{array}{l}\text { Private transport } \\
\text { ps-km (billion) }\end{array}$ & \# of EVs \\
\hline France & 61.5 & 29.2 & 41 & $720(2001)$ & 7,744 \\
U. S. & 288.2 & 228.9 & $77.6(2001)$ & $7136(2001)$ & $5,200(2000)$ \\
California & 35 & 29.1 & N.A. & 841.9 & $3,900^{\mathrm{a}}$ \\
\hline
\end{tabular}

*Except where noted. Passenger-km (ps-km): One passenger traveling the distance of one km. Total passenger$\mathrm{km}$ traveled gives the total distance traveled by all people. Sources: (1) Population: Census Bureau, 2005 (US and CA); Institut National de la Statistique et des Etudes Economiques (Insee), 2004 (France); (2) Motor vehicle registrations: FHWA, 2003 (US and CA); Comité des Constructeurs Français d'Automobiles (CCFA), 2003 (France); (3) Passenger Activities: FHWA, 2003 (US and CA); CCFA, 2003; (France); (4) Motor Vehicles: FHWA, 2003 US; CARB, 2002 (CA); CCFA, 2003 (France); (5) EVs: Joyce, 2001, (US); Cackette, 2003 (CA); Groupe Interministériel Véhicules Electriques (GIVE), 2003 (France)

${ }^{a}$ The highest number of EVs in California and in the US was recorded in 2000. Since then, the number has been declining due to the recall by Ford, Honda and GM of their EV models (Fagan, 1999; Maynard, 2002; Glover, 2000; GM, 2002).

with the most frequent violations of the federal standard. ${ }^{6}$ Moreover, the CARB maintained that projected increases in VMT (384 billion in 2010 and 475 billion in 2020) would slow and, possibly, reverse the decline in ozone levels (Caltrans, 2001). Along with the rise in miles driven, the main reason for the inadequacy of emission reduction improvements is the stagnation in automobile fuel economy over the last eighteen years. In 1987, the combined (cars and trucks) fleet fuel economy was 25.9 miles per gallon (mpg) and in 2004 it was 24.4 $\mathrm{mpg}$ (EPA, 2005a). The decline in fuel economy is largely due to the growth ( $27 \%$ in 1987 to $48 \%$ in 2004) of the market share of sport utility vehicles (SUV) and light trucks, which are about a third less fuel-efficient than passenger cars (EPA, 2005a). The increasing popularity of SUVs and light trucks, subject to lax government fuel efficiency standards, as well as the rise in VMT has largely offset the air quality gains brought by pollution reduction technologies (catalytic converters, fuel injection, variable valve control). Furthermore, throughout the period under examination, the worsening urban traffic congestion produced by growth in car-based mobility precipitated adverse social consequences (e.g. gridlock, rising volumes of polluting exhaust and monetary losses (Shrank and Lomax, 2002). ${ }^{7}$

In France, the transportation system has provided French residents with a high level of personal mobility, although less than that enjoyed by Americans. ${ }^{8}$ See Table 2 for a comparison of transportation data in France, the United States and California).

But, as in the United States, the growth in automobile mobility has worsened air quality. In 1993, two years before a major French EV legislative act was enacted, cars, trucks and buses produced about half of the ozone-forming hydrocarbons, $60 \%$ of all the carbon monoxide pollution and $68 \%$ of the oxides of nitrogen (NOx), $90 \%$ of lead and $41 \%$ of the particulates (Centre Interprofessionel Technique d'Etudes de la Pollution Atmosphérique (CITEPA), 1998). And if between 1980 and 1993, as Table 3 shows, total (i.e. from industrial, service and transportation sectors) emissions of $\mathrm{NO}_{x}$ have declined considerably, the contribution

\footnotetext{
${ }^{6}$ In 1987 , California set a state standard for ozone equal to $0.09 \mathrm{ppm}\left(180 \mu \mathrm{g} / \mathrm{m}^{3}\right)$ for a 1-hour averaging time. There are many areas in the state where the state standard for ozone is exceeded more than a hundred times per year (SCAQMD, 2003).

${ }^{7}$ According to the Texas Transportation Institute (TTI), in 2001, three California cities (Los Angeles, San Francisco-Oakland and San Jose) ranked in the Institute's top ten list of the most congested cities in the US.

${ }^{8}$ With 520 cars per 1,000 inhabitants, France reached in 1995 the level of motorizations attained in the early 1970s in the United States (CCFA, 2003).
} 
Table $3 \mathrm{NO}_{x}$ emissions (total and from the transportation sector) in France 1980-2003

\begin{tabular}{lrrrrr}
\hline Pollutant & 1980 & 1990 & 1993 & 2000 & 2003 \\
\hline France $\mathrm{NO}_{x}$ total & 1989 & 1830 & 1742 & 1390 & 1220 \\
France $\mathrm{NO}_{x}$ transport & 827 & 1093 & 1090 & 728 & 586 \\
\hline
\end{tabular}

Data are in kilotons.

Source: CITEPA, 2005

Table 4 California standards for light vehicles

\begin{tabular}{llll}
\hline Category & NMOG $^{\mathrm{a}}(\mathrm{g} / \mathrm{mile})$ & $\mathrm{CO}(\mathrm{g} / \mathrm{mile})$ & $\mathrm{NOx}(\mathrm{g} / \mathrm{mile})$ \\
\hline CV $^{\mathrm{b}}$ & 0.250 & 3.4 & 0.4 \\
TLEV & 0.125 & 3.4 & 0.4 \\
LEV & 0.075 & 3.4 & 0.2 \\
ULEV & 0.04 & 1.7 & 0.2 \\
ZEV & 0.000 & 0.0 & 0.0 \\
\hline
\end{tabular}

Source: CARB, 1990.

a Non-methane organic gases (i.e. hydrocarbons with the exclusion of methane).

${ }^{\mathrm{b}}$ Conventional vehicles

of the transport sector to $\mathrm{NO}_{x}$ emissions output over the same period did not decline. $\mathrm{NO}_{x}$ emissions from cars and trucks started to decline only in 1994.

Although new cars met ever stricter standards, in several metropolitan areas, including those of Grenoble, Lyon, Marseilles, and Paris, air quality remained far from satisfactory throughout the 1990s owing to the increase in volume of road traffic (Patel, 1995). Ile-de-France, the region around Paris where 19\% of the French population (11 million people) lives, has received the greatest attention because it is one of the most polluted and politically important areas of the country.

\section{The California ZEV mandate}

In September 1990, convinced of the inadequacy of existing federal air quality standards, the CARB proposed new regulations based on new definitions of types of vehicle as a policy to reduce motor vehicle emissions in California. The proposal required the phased introduction of low-emission vehicles and the clean fuels needed by them. The low-emission vehicles were to meet one of four sets of exhaust emission standards. The emission standards (shown in Table 4) established by the Board were: Transitional Low-Emission Vehicles (TLEVs), Low Emission Vehicles (LEVs), Ultra-Low-Emission Vehicles (ULEVs) and Zero-Emission Vehicles (ZEVs) (CARB, 1990).

Unlike the standards for TLEVs, LEVs and ULEVs, those for ZEVs could not be met by means of gasoline-powered cars, even those equipped with the most advanced emissioncontrol technology available. The portion of the new regulations that dealt with ZEVs (hereafter the ZEV mandate) required that $2 \%$ of all passenger cars and light trucks (less than 3750 lbs. loaded vehicle weight) sold in the state by every major car manufacturer must emit zero exhaust, beginning with the 1998 models. ${ }^{9}$ The percentage of zero emission vehicles was to

\footnotetext{
${ }^{9}$ The category of "major manufacturers" denoted all those whose sales equaled at least 35,000 units in the state and included Chrysler, Ford, GM, Honda, Mazda, Nissan and Toyota. 
increase to 5\% in 2001 and to $10 \%$ in 2003 . The CARB could fine an automaker failing to meet the ZEV requirement up to $\$ 5000$ for each violation.

Although strongly opposed to the mandate, Chrysler, Ford and General Motors (GM) responded to the challenge presented by the CARB by forming, together with the Department of Energy (DOE) and the Electric Power Resource Institute (EPRI) (representing the electric utilities), the U.S. Advanced Battery Consortium (USABC). The primary objective of the consortium was to improve existing battery technology, as it was generally assumed that, without major improvements in that sector, no electric vehicle meeting a satisfactory range $(\sim 100$ miles with one charge) would be ready by 1998.

In 1992 and 1994, the CARB reviewed the status of technological progress and upheld the mandate in its original form. The CARB focused on the state of the art of battery technology, which was recognized by most stakeholders as the Achilles' heel of electric cars. In the early 1990s, the few types of batteries considered reliable (e.g., lead-acid, nickel-cadmium) were also the ones that provided the most disappointing performance. In 1995, the CARB commissioned an assessment of the current state and the future prospects of battery technology. The study (Kalhammer et al., 1995) concluded that: (a) lead-acid (Pba) and nickel-cadmium battery technology had improved significantly during the early 1990s and could be deployed in 1998, although some of their characteristics would remain well below the midterm criteria set by the USABC; (b) several types of advanced batteries (nickel-metal hydride, lithium ion, sodium-nickel chloride) showed excellent promise to meet the USABC midterm goals and were good enough to allow the development of pilot-scale production; (c) the plans to initiate commercial-scale battery production $(10,000-$ 40,000 battery packs per year) depended on commitments made by car manufacturers to buy batteries on that scale; and (d) the battery manufacturers and researchers interviewed by the panel were unanimously convinced that the ZEV mandate had accelerated investment and progress in developing advanced batteries for electric vehicles. Further progress hinged on a stable program aimed at developing EVs with advanced batteries. Finally, in a best-case scenario, with no technical or decision delays in any of the various development phases, electric vehicles powered by advanced batteries could become available in 2000 or 2001.

By the end of 1995, the CARB technical staff reached conclusions reflecting those contained in the expert assessment (CARB, 1995):

1. Lead-acid batteries remain the primary high-volume option for 1998 electric vehicles, but would not be able to satisfy long-term requirements such as reasonably long vehicle driving range per electric charge.

2. Although some advanced batteries (i.e., non-lead-acid) would be available by 1998, high production volumes of advanced batteries were not expected until 2001.

3. The existing ZEV requirements should be altered to be more responsive to these issues.

In March 1996, the CARB suspended the ZEV requirements for the model years between 1998 through 2002, replacing them with an agreement under which the automakers committed to introduce electric vehicles as early as 1996 and to supply as many as $3750 \mathrm{EVs}$ ( $0.02 \%$ of all the cars sold in California in one year) between 1998 and 2000. The CARB also worked out separate Memoranda of Agreement (MOAs) with each of the seven automakers subject to the ZEV requirement. According to the MOAs, automakers would manufacture cleaner light-duty vehicles nationwide by 2001 and would continue the R\&D efforts aimed 
at introducing large volumes of EVs by $2003^{10}$. For its part, the CARB was obligated to work with the state and local authorities to ensure the development of ZEV infrastructure, remove barriers to the introduction of ZEVs and contribute to the implementation of incentive programs for ZEVs (CARB, 1996a). If the automakers breached the MOAs by failing to fulfill their obligations, the CARB had the authority to reinstate the provisions of the original ZEV mandate and to impose damage penalties of up to $\$ 100$ million for breach of contract.

In 1995, the CARB staff had discussed possible amendments to the Low Emission Vehicle (LEV) regulation in order to provide greater flexibility to the auto industry to meet California's emissions requirements. After having reviewed the existing information about the technology of hybrid electric vehicles (HEVs), CARB staff proposed that HEVs with an all-electric range of at least 30 miles could receive partial ZEV credits (CARB, 1995) ${ }^{11}$ but in June 1996, CARB decided to drop the proposal of partial ZEV credits for HEVs (CARB, 1996b). Two years later, CARB changed its mind about hybrid technology: hybrid electric vehicles had become increasingly attractive to policymakers because they did not require exotic technology and provided already substantial benefits towards the goals of automobile emission reduction and fuel-efficiency improvements. ${ }^{12}$ The HEV models offered on the US market after 1999 provided the same range drivers expected from Internal Combustion Engine Vehicles (ICEVs), did not suffer from the recharging-time problems (whether perceived or real) of EVs and were significantly more fuel efficient than most conventional gasoline cars. ${ }^{13}$ At the end of 1998, the CARB amended again the mandate introducing a new category of extremely clean cars: the super ultra low emission vehicle (SULEV) standard that stood to gain partial zero emission vehicle (PZEV) credit toward the $10 \%$ requirement. ${ }^{14}$ Under the 1998 amendments, $4 \%$ of the cars offered for sale by the automakers had to be electric, while the remaining $6 \%$ of the original $10 \% \mathrm{ZEV}$ requirement set for 2003 could be met with PZEVs (CARB, 1999).

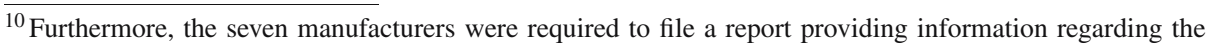
number and type of ZEV placed in California and in the United States and data about the purchase of advanced battery technology within ninety days following the close of each year.

${ }^{11}$ Hybrid electric vehicles are equipped with two power sources: an internal combustion engine coupled to an electric motor. For a review of HEV technology see Wouk, 1995.

${ }^{12}$ Models currently available on the markets are not designed to operate exclusively with the electric motor. Such capability, however, could produce further benefits by controlling when and where emissions occur. With appropriate batteries (NIMH for example) that allow for a significant all-electric range, HEVs can be driven as ZEVs and can thus further contribute to the original CARB emission-reduction goal. The idea that HEVs could significantly reduce exhaust pollution and fuel consumption in targeted areas at particular times was advanced already in the 1960s (Hoffman, 1967; Wouk, 1976).

${ }^{13}$ In 2003, the EPA rated the fuel economy of a Honda Civic hybrid to be $48 \mathrm{mpg}$ (combined city/highway cycle) whereas a conventional Honda Civic was estimated to achieve only $37 \mathrm{mpg}$ (EPA, 2003a). According to EPA tests, the 2004 Toyota Prius gets $60 \mathrm{mpg}$ in the city and $51 \mathrm{mpg}$ on the highway (EPA, 2005b). In 2005 the product-rating organization Consumer Reports found that the EPA overstates hybrid vehicles mileage by failing to reflect actual on-the-road driving conditions (Consumer Reports, 2005). Consumer Reports' analysis shows that although discrepancies between the EPA fuel efficiency ratings and "real world" fuel economy exist for all types of vehicles, the biggest differences are for hybrids. Nonetheless, hybrids remain among the most fuel efficient vehicles available on the market (Murphy, 2005). On the fuel economy of hybrids see also Duoba, Lohse-Busch, and Bohn, 2005.

${ }^{14}$ The creation of the new SULEV standard reflected the advancements of technology for gasoline, hybrid and alternative fuel vehicles. In the spring of 1998, Honda had already offered for sale in California a compressed natural gas vehicle with emission levels at one tenth of ULEV and Toyota had begun selling the Prius, its first hybrid electric vehicle (CARB, 1998a). SULEVs emitted $0.010(\mathrm{~g} / \mathrm{mi})$ of NMOG, $1.0(\mathrm{~g} / \mathrm{mi})$ of CO and 0.02 $(\mathrm{g} / \mathrm{mi})$ of $\mathrm{NO}_{x}(\mathrm{CARB}, 1998 \mathrm{~b})$.
} 
Ten years after the ZEV mandate was first proposed, the most crucial uncertainty about the feasibility of large volume sales of EVs concerned the cost and the performance of rechargeable batteries. In order to answer lingering questions about recent progress made by battery manufacturers, the CARB contracted a second battery-technology assessment in June 2000, which produced a second report about batteries. The panel concentrated its investigation on advanced batteries having estimated that lead-acid and nickel-cadmium batteries would not provide the performance expected by large numbers of customers. According to the panel's findings the best candidate EV-battery was NiMH (Nickel-Metal Hydride). On the basis of the battery panel assessment, the CARB biennial review held in September 2000 confirmed the requirement for 4\% pure ZEVs by 2003.

In January 2001, the CARB approved new amendments requiring that, by 2003, only $2 \%$ of the cars (roughly equivalent to $4650 \mathrm{EVs}$ ) were to be pure ZEVs, another $6 \%$ to be PZEVs and the remaining $2 \%$ as advanced technology partial zero emission vehicles (ATPZEVs) (natural gas, hybrid electric), capable to satisfy the SULEV standards and having near-zero evaporative emissions with an 15-year/150000 mile warranty for the emission control equipment (CARB, 2001). From the early 1990s until 2002, at any given time, there were never more than $3900 \mathrm{EVs}$ in California, half of which were owned by government and utility fleets (Cackette, 2003)

\section{Technology-forcing and the biennial review mechanism}

The CARB staff recognized that one of the most delicate issues of the LEV regulations was the technological feasibility of the proposed standards. Indeed the first CARB proposal for the LEV regulation admitted that:

The requirement for ZEVs is based on the projected viability of electric vehicles after receiving input from vehicle manufacturers and electric vehicles design engineers. It is widely acknowledged that further research and development will be needed before vehicles capable of meeting the emission standards in use are ready for commercial production (CARB, 1990).

In order to monitor the progress made by automobile manufacturers, the technical team of CARB claimed that "it would continue to work closely with the vehicle and fuel industries in implementing the regulations and identifying any appropriate changes to the regulations that may be needed in the future." The staff recommended that it would report back to the Board every two years on the implementation of the ZEV program.

Although in 1990, battery technology was still costly and no breakthroughs had occurred for many years, the CARB's selection of electric vehicles as an appropriate technology to reduce the problem of urban air quality was not haphazard. As was true of other past technology-forcing regulations, the ZEV mandate expected that the industry was relatively close to developing a viable technology (La Pierre, 1977; Ashford et al., 1985). Indeed, after a prototype program was launched by GM in the late 1980s, the CARB staff thought that the EV technology option was realistic. ${ }^{15}$

\footnotetext{
${ }^{15}$ In the late 1980s, GM invested considerable financial and human resources on a program to manufacture an electric car, the Impact, a prototype that became in 1996, under the name EV1, the first EV offered for sale by a major American automaker. GM took advantage of the massive conversion programs at the end of the Cold War that redirected the resources of large military industrial companies (such as Hughes and Rockwell, both GM subsidiaries) toward civil and commercial production (Shnayerson, 1996; Scott, 1995).
} 
The success of the ZEV program depended greatly on the CARB's ability to design an appropriate regulatory strategy to facilitate the emergence of a cost-effective and reliable EV. In this respect CARB made several decisions that illustrate the agency's effort to consider new technological developments and address industry's concerns without weakening the technological momentum created by the mandate. Critically, CARB postponed the deadline for the first ZEV requirement from 1998 to 2003 and allowed automakers to gain ZEV credits by means of hybrid cars that had unexpectedly benefited from the advances in battery technology. ${ }^{16}$

Although formally the CARB allowed automakers their choice of technology to meet the ZEV requirements, EVs were the only feasible option when the mandate was conceived. Indeed the ZEV mandate sparked an international revival of EV technology that had been dormant for decades. American, French and Japanese automakers that had neglected research on EVs and advanced batteries throughout the 1970s and the 1980s resumed their interest in it mainly as a result of the ZEV mandate (Cornu, 1998; Sato, 2001). Created in 1990 as a public policy biased in favor of the development of battery-powered electric cars, the ZEV regulation ended up accelerating the development of other clean-vehicle technologies, such as fuel cells, which many consider a promising long-term clean propulsion technology for automobiles (Ogden, 1999). ${ }^{17}$ Discussing the development of fuel cells, Firoz Rasul, CEO of Ballard Power Systems, one of the leading firms in fuel cell R\&D, acknowledged that the mandate functioned as a catalyst for the development of the new technology. In 2001, Rasul remarked:

It's not just going to happen by market forces. . . I can certainly tell that Ballard would not be here today, if it was not for the zero emission vehicle regulation set in 1988 . Without that requirement we could not have raised the money (Rasul, 2001).

\section{Reactions to the ZEV mandate}

Predictably, the strict standards imposed by the ZEV mandate caught the attention of many interest groups in California and in the rest of the country eliciting a vast array of reactions. Perceiving the appearance of EVs as a direct threat to their monopoly on fuels for automobiles, the oil companies were bluntly hostile to the ZEV mandate while the major automakers were at best reluctant to reconfigure their industry around electric motors powered by rechargeable batteries. ${ }^{18}$ On the other hand, electric utilities saw the CARB's regulations as an opportunity to expand their markets and optimize the existing electricity generating capacity. Indeed, a market for EVs would affect utility rates (Ford, 1994) and would also create potential

\footnotetext{
${ }^{16} \mathrm{HEV}$ technology was spurred on by the Partnership for a New Generation of Vehicles (PNGV), an R\&D program developed jointly by several US government agencies and the three main American automobile companies in 1993 to produce a passenger car with a fuel economy of $80 \mathrm{mpg}$ (National Research Council, 1996; DOE, 2002b). Over the years, various commentators have debated the real effectiveness of the PNGV program (which was terminated in 2002 to make way for the FreedomCar program) in advancing the development of HEVs (Sperling, 2002; Malakoff, 1999).

${ }^{17}$ In light of the potential of fuel cells to power zero emission vehicles and given the similarity of certain components that exist both in battery- and fuel cell-powered vehicles (the electric drivetrain for instance), the CARB mandate was instrumental in persuading venture capitalists to invest money in companies such as Ballard (Rasul, 2001).

${ }^{18}$ Both the automobile manufacturers and the oil companies claimed that the electric vehicles available on the market had one crucial shortcoming (limited driving range) and were too costly to be marketable. See Rienzeman, 1995 and Henriksen et al., 1994 for a review of the main features of rechargeable battery technology and battery-powered motor vehicles.
} 
new customers. Environmental groups and public health organizations welcomed the ZEV mandate, but were not as forceful in their support as the oil and the auto industries were in their opposition to it. Within a year of the mandate's approval, both the oil and the auto industry engaged in a vigorous campaign to oppose the CARB regulation. The degree of hostility towards the mandate was different for the two industries since the stakes were different. Whereas automakers would continue to manufacture automobiles regardless of the regulations, in the long run oil companies risked the loss of significant fraction of the market and perceived the emergence of electric vehicles as a long-term threat to their business.

The anti-EV camp employed many strategies to influence the outcome of the policy decision-making process including: ${ }^{19}$ political contributions, advocacy advertising, funding of studies, traditional lobbying and astroturf lobbying, and challenges in the courts.

\section{Lobbying and public relations}

With considerable financial resources and political clout at their disposal, the anti-EV camp made extensive efforts to influence the public debate about the mandate. The oil companies indirectly influenced public policy formulation by contributing money to candidates for political office. Atlantic Richfield Co., BP America, Exxon, Mobil Oil Co., Phillips Petroleum, Shell Oil Co. and Texaco donated a total of \$1.1 million to legislative candidates in 1994 and in the first six months of 1995. During the same period, the auto industry donated \$276000 (Kasnitz and Mashke, 1996). In particular, California's governor Pete Wilson received $\$ 325000$ and $\$ 76000$ from oil and auto industry groups, respectively.

Mobil Oil Corporation attempted to secure the approval of the general public through advocacy advertising. The company regularly purchased advertising space in the New York Times, USA Today, the Wall Street Journal, the Washington Post and large-circulation news magazines such as Newsweek and Time, spending an estimated \$3.5 million (Kasnitz and Mashke, 1996). Aimed at discrediting all potential alternative fuel vehicles, including electric cars, the Mobil campaign sought to accomplish three things:

1. Reassure customers that the world was not running out of oil. As part of the Clearing the Air series, the Running out of oil? ad (Mobil, 1995a) warned readers that a "sizeable number of regulators and politicians are pushing mandates and subsidies to drive the public to buy alternative fuel vehicles." 20

2. Illustrate the inadequacy of EV technology as a means of transportation for the average American and discredit their environmental benefits. ${ }^{21}$ An ad titled Who pays for plugging in? reassured the general public that: "We have no problem with electric cars competing in the marketplace. We do have a problem, though, with mandates, particularly mandates

\footnotetext{
${ }^{19}$ Note that the LEV program was subject to a biennial review designed to confirm the requirements or alter those that were bound to face problems of technological feasibility.

${ }^{20}$ Curiously, the ad was intended to comfort readers with the assertion that "at current consumption rates there is enough oil to support our planet's petroleum needs for about 45 years." Indeed the estimates of world total oil proven reserves collected by the Oil \& Gas Journal over the period 1990-2000 averaged at about 1000 billion barrels. Assuming that demand does not increase, i.e. at current consumption levels ( $\sim 75$ million barrel/day), the world would run out of relatively cheap oil in 41 years. According to Mobil's own literature the world's oil reserves will be severely depleted before 2050 .

${ }^{21}$ One ad (Mobil, 1995b) reported the findings of a study carried out at Carnegie-Mellon University widely considered very partial against EVs. See Socolow and Thomas, 1997 for a critical review of the study and also the next section of this article.
} 
at this time that would lock in our current electric technology. That technology simply is not good enough."

3. Foster the values of the free-market system, which Mobil saw as threatened by everexpanding government regulations.

4. Stir up economic apprehension by arguing that the mandate would cause tax increases.

The oil industry did not limit itself to advocacy advertising. Concerned that the general public would be skeptical of positions taken by "big business," oil companies also resorted to astroturf lobbying, a strategy whereby corporations conceal their involvement in lobbying initiatives behind the guise of grassroots movements. ${ }^{22}$ Western States Petroleum Association (WSPA), a trade organization of the oil industry, mobilized two consumer groups that ordinarily lobby to keep utility bills low: Toward Utility Rate Normalization (TURN) and Utility Consumer's Action Network. Over the course of the anti-ZEV campaign, a group called Californians Against Utility Company Abuse (CAUCA) was set up by oil companies in order to promote senate bill SB 1819 and assembly bill AB 3239 which would have prevented the legislature from using utility revenues to develop an infrastructure for natural gas and electric vehicles. ${ }^{23}$ To further its astroturf strategies, WSPA also created artificial grassroots movements such as Californians Against Hidden Taxes (CAHT) and the National Institute for Emergency Vehicle Safety. ${ }^{24}$

Ultimately the essence of the automakers' and oil companies' lobbying efforts could be found in a Request for Proposal issued in the spring of 1995 by the American Automobile Manufacturers Association (AAMA), an organization that includes Chrysler, Ford and General Motors. While it acknowledged that "Recent surveys indicate a majority of Californians believe zero emission vehicles (ZEVs) are a 'workable and practical' means of reducing air pollution," the Proposal's objective read as follows: "The AAMA is conducting a search for a qualified contractor to manage a statewide grassroots and educational campaign to create a climate in which the state's mandate requiring automakers to produce a fixed percentage of electric vehicles beginning in 1998 can be repealed" (AAMA, 1995).

Industry groups that favoured the ZEV mandate did not refrain from using astroturf tactics either, although they did so primarily in response to the oil industry efforts. Electric utilities hired a PR firm, PS Enterprises, to organize the Santa Monica-based Californians for Jobs and Clean Air (CJCA). The main objective of CJCA was to create press releases aimed at counteracting the oil industry's bleak news about the effect of EVs on the California economy. ${ }^{25}$ In typical astroturf style, the press releases did not disclose

\footnotetext{
${ }^{22}$ Astroturf refers to the synthetic grass product.

${ }^{23}$ CAUCA, managed by the public relations firm Woodward \& McDowell, sent a letter to 200,000 ratepayers urging them to protest against the proposed $\$ 600$ million utility investments in alternative support systems. The letter, signed by TURN executive director Audrie Krause and by Howard Owens, director of Congress of California Seniors, made no mention that it had been written by Woodward \& McDowell or that the whole effort had been paid by the WSPA. CALPIRG estimated that WSPA gave \$1 million to Woodward \& McDowell over a period of 20 months (Kasnitz and Maschke, 1996).

${ }^{24}$ Campaign and Elections magazine described astroturf as "grassroots program that involves the instant manufacturing of public support for a point of view in which either uninformed activists are recruited or means of deception are used to recruit them" (Faucheux, 1995). Astroturf coalitions are distinguished from genuine grassroots movements because they are created or co-opted by public relations firms for their corporate clients. See Graebner, 1995, Grefe and Linsky, 1995 and Beder, 1997.

${ }^{25}$ Unlike automobile manufacturers and oil companies, California's electric utilities were not hostile to the ZEV mandate. Utility companies assumed that most of EV charging would occur at night thus opening a new market exploiting idle off-peak generation capacity. As in many other states in the U.S., California could benefit from replacing ICEVs with EVs since state electricity is produced from relatively clean fuel sources. In 
the origin of the funding for CJCA which was a consortium of electric utilities (Parrish, 1994).

Studies about the ZEV mandate

The campaign run by interest groups to discredit or to support EVs and the ZEV mandate borrowed technical arguments from the debate that took place among scientists, engineers and policy analysts who assessed the new technology. Between 1993 and 1996, researchers around the country analyzed the technical and the policy issues involved in the ZEV mandate. In several cases, the technical expertise offered during the crucial years of the mandate turned out to be almost as tendentious as the rhetoric that fueled the slogans of lobbyists and PR officials. Indeed, quite a few studies produced to discredit EVs made assumptions that either conflicted with undisputed data or, more subtly, emphasized the weaknesses of EVs, omitting their strengths. These studies happened to be the ones that attracted the most attention from the media.

The honor of opening the first round of salvos against the ZEV mandate went to Sierra Research (SR), a consulting firm based in Sacramento, California, which published five reports on the emission benefits and the cost-effectiveness of California's low-emission vehicle regulation. Funded by the AAMA, the report "The Cost-Effectiveness of Further Regulating Mobile Source Emissions" concluded that: "The ZEV mandate does not appear to be a cost-effective control strategy even assuming that new car sales volumes are unaffected and power-plant emissions are zero" (Sierra Research, 1994). ${ }^{26}$ To reach these conclusions SR had to discount emission reductions achieved by EVs in attainment areas or during seasons with no air quality standards violations, effectively treating those reductions as without value. Furthermore, in comparing EVs and ICEVs, SR analysis ignored the vehicles' operating costs and considered only initial vehicle costs, thus giving an unfair advantage to ICEVs, whose operating costs are higher than those of EVs.

The Sierra Research reports were greeted warmly among groups hostile to the ZEV mandate. Shortly thereafter, another study brought the controversy to the national stage. In May 1995, Science published the results of the study "Environmental Implications of Electric Cars," ${ }^{27}$ conducted at Carnegie-Mellon University by L.B. Lave, C.T. Hendrikson and F.C. McMichael. ${ }^{28}$ The thrust of the report was that, since the mandate would require the use of many electric vehicles powered by lead-acid batteries, lead emissions would increase and pose a threat to American citizens. The authors concluded that "electric cars do not deliver the promised environmental benefits" and that "a 1998 model electric car is estimated to release 60 times more lead per kilometre of use relative to a comparable car burning leaded gasoline" (Lave, Hendrikson and McMichael, 1995). Lamentably, the article contained several errors

the mid 1990s, more than $32 \%$ of the electricity consumed in the state was produced by renewable resources, almost $15 \%$ came from nuclear energy, and about $15 \%$ from natural gas (California Energy Commission, 2002).

${ }^{26}$ During the public workshops sponsored by CARB in 1995 several organizations hostile to the mandate, including some astroturf groups, cited the SR's bleak conclusions about the ZEV regulations' effectiveness (Mangels, 1995; Dale, 1995).

${ }^{27}$ The title of the article implied that all EVs use lead-acid batteries, whereas it is generally known that lead-acid batteries are only one type of the batteries that power EVs.

${ }^{28}$ The technological assessment carried out at Carnegie-Mellon was partly funded by Green Design Consortium, a coalition of industrial groups that included Exxon Research and Engineering, GM-Delco Chassis, GM-Packard Electric, Mobil R\&D, and Shell Development (Kasnitz and Maschke, 1996). 
that undermined the dramatic conclusions reached by the authors. Lave and coauthors used obsolete data indicating, for instance, that the energy density of the lead-acid battery used in the General Motors Impact ${ }^{29}$ was 18 Watthour per kilogram $(\mathrm{Wh} / \mathrm{kg})$ while the figure given by $\mathrm{GM}$ was $40 \mathrm{Wh} / \mathrm{kg}$ (GM, 1996). Although this error was corrected in the accompanying text, it appeared that all the calculations were based on the incorrect figure. The battery mass for the Impact was listed as $1378 \mathrm{~kg}$ (but it was $522 \mathrm{~kg}$ according to GM) which was greater than the entire mass of the car $(1350 \mathrm{~kg})$. According to Lave et al., the Impact's range was 50 miles when GM estimated it to be at least 70 miles.

In order to estimate the amount of lead emissions in the environment Lave and co-authors assumed that the lead used in the batteries was virgin-mined lead, when in fact about $97 \%$ of lead batteries is recycled and only a fraction is produced from virgin lead. Furthermore, the article did not differentiate between the air-borne emissions of lead and lead solid waste which is relatively easier to monitor. ${ }^{30}$ In 1996 further skepticism about the environmental benefits of EVs emerged in a study carried out at the Massachusetts Institute of Technology (MIT) (de Neufville et al., 1996), but the study had faults comparable to Lave et al.: thus the setbacks encountered by sodium-sulphur batteries were mentioned but the achievements of $\mathrm{NiMH}$ were not. The MIT researchers claimed that the average life span of several advanced batteries did not reach the 1.5-2 years range when in fact it does (Karlhammer et al., 1995). Furthermore, their assertion that supplying additional electric loads to power EVs would inevitably require using dirty and inefficient power plants is refutable since electric utilities' emissions vary greatly depending upon the energy mix and, in many cases, EVs have been shown to provide net environmental benefits (U.S. GAO, 1994; MacKenzie, 1994).

\section{The ZEV mandate and the courts}

It is not surprising that, in a country where the law has traditionally played a central role in the solution of public policy issues, the controversy about the ZEV mandate became the subject of judicial review. ${ }^{31}$ Indeed, as various versions of the ZEV mandate were adopted, practically all the parties affected engaged in recurring actions to challenge them in courts around the country. In May 1992, Massachusetts and New York adopted the California LEV plan, including the ZEV mandate. Less than two months later, the Motor Vehicle Manufacturers Association of the United States (MVMA) and the Association of International Automobile Manufacturers (AIAM) filed a suit against the New York Department of Environmental Conservation (Motor Vehicle Manufacturers Association of the U.S., Inc. v. New York State Department of Environmental Conservation, 810 F. Suppl. 1331, 1993, hereafter MVMA, 1993). The automobile manufacturers complained that the LEV rules adopted by the state of

\footnotetext{
${ }^{29}$ The Impact and the EV1 are the same car. Believing that the first name lacked consumer appeal, GM renamed the car.

${ }^{30}$ Lave, Hendrikson and McMichael carried their analysis further in Environmental Science and Technology (Lave et al., 1996) where they claimed that the health hazards derived from EVs powered by $\mathrm{PbA}$ batteries compared unfavorably with those associated with the use of vehicles powered by leaded gasoline. The EST article became the subject of a thorough assessment carried out at the Center for Energy and Environmental Studies at Princeton University. The authors of the assessment challenged Lave et al. by stating that the hazards of lead-acid batteries and those of lead additives in gasoline were not comparable (Socolow and Thomas, 1997).

${ }^{31}$ The US is known for its inclination to resolve public policy issues by means of formal, adversarial processes. Policy disputes in the US often involve legal rules, punitive sanctions and calls for judicial intervention. In contrast, in most other industrialized nations, advocacy and interest groups prefer informal methods to settle policy disputes, and judicial intervention is an exception rather than the rule. For a comprehensive critical analysis of American “adversarial legalism," see Kagan, 2001.
} 
New York violated the "third vehicle" 32 provision of Clean Air Act Section 177 since New York had not adopted the clean fuels portion of the California's LEV program.

The American Auto Manufacturers Association also sought to enjoin implementation of tailpipe emissions regulations adopted by the Massachusetts Department of Environmental Protection (DEP) (American Auto Manufacturers Association v. Massachusetts D.E.P., 31 F.3d, 18 First Circuit, 1994, hereinafter AAMA, 1994). The action suits filed against the two Northeast states were similar: the automobile manufacturers claimed that the rules adopted by Massachusetts and New York were pre-empted by the Clean Air Act (CAA). In 1994, the court of appeals upheld the adoption of LEV regulation, but in 1997 the court ruled that Massachusetts DEP ZEV regulations were not identical to California standards as required by CAA Section 177 and thus, were pre-empted by CAA Section 209(a) (AAMA, 1998). In the following years, automakers and car dealers, in Massachusetts and in New York, repeatedly took action against the two states' environmental departments, usually following the ZEV mandate revision cycles (Association of International Automobile Manufacturers (AIAM, 2000; Daimler Chrysler et al., 2002).

In 2001, General Motors filed a suit in California to overturn the mandate, alleging, among other things, that the CARB ignored the financial impact of the mandate on automakers (O'Dell, 2002). The next year, General Motors, DaimlerChrysler and several car dealers filed a second suit in California challenging the ZEV regulations on the grounds that the provisions pertaining to gasoline-electric hybrid vehicles were related to fuel economy standards and, as such, were preempted by the Energy Policy and Conservation Act, the federal law that established the CAFE standards in 1975 (US Court of Appeals, 2002.) Subsequently several environmental and public interest groups filed a amicus briefs on behalf of the state of California (Hwang, 2002), whereas private individuals, car dealers and the federal government filed such briefs on behalf of the plaintiffs (Central Valley Chrysler-Plymouth, INC. et al. v. Michael Kenny, 2002).

Environmental groups outside California also used the legal system to pursue policy goals in the courts. In January 1996, shortly before the MOA were signed by the automakers and the CARB, the Sierra Club Legal Defense Fund (now the Earth Justice Legal Defense Club) filed an antitrust complaint against the automakers and the oil industry. According to the Fund's allegations, federal and state anti-trust laws had been violated by the industry in an effort to derail California's LEV program. The Department of Justice investigated the charges (Electric Utility Week, 1996) but eventually rejected the case (Becker, 1998).

\section{The French model of EV development}

There are two good reasons to contrast the EV policies pursued by the CARB with France's. First, roughly at the same time the ZEV mandate was developed, French regulators also developed a strategy that aimed at promoting EVs. Secondly, France was home to two prominent car companies, Peugeot and Renault, two major battery manufacturers, Saft and CEAC and Electricité de France (EDF), a large, resourceful national electric utility.

\footnotetext{
${ }^{32}$ For the purposes of the Clean Air Act (CAA), California is treated differently than the other forty-nine states on account of its particularly severe air pollution problems and for having led the nation in the fight against air pollution since the late 1950s. The CAA (title 42, United States Code section 7507) allows California to enact its own standards for motor vehicle emissions. Other states can adopt California's standards instead of federal standards, but these must be identical to California's standards, so as to not create a third set of standards, forcing automakers to produce a "third vehicle."
} 
In the early 1990s, the worsening of air quality in French urban centers led to substantial activity in the policy and legislative arena. In 1994 the results of the project ERPURS (Evaluation des Risques de la Pollution Urbaine pour la Santé) Impact de la Pollution Atmospherique sur la Sante en Ile-de France: 1987-1990, an epidemiological study on the effects of atmospheric pollution on human health in the Ile-de-France were published. The study established a quantitative linkage between the levels of $\mathrm{NO} x, \mathrm{SO}_{2}, \mathrm{O}_{3}$ and the number of deaths and hospitalizations in the region around Paris (Medina et al., 1994). The results of the study were reported several times in the daily press and left little doubt about the seriousness of the air pollution problem in the Ile-de-France (Kremer, 1995; Normand, 1995).

Providentially for the politicians who were under pressure to address the problem of air pollution, France was in a favorable situation for the development of electric vehicles for the following reasons:

1. The dense layout of French urban centers makes the use of EVs less problematic than it is in the US. Recent surveys indicate that local (within $80 \mathrm{~km}$ ) travel by car accounts for $95 \%$ of total car travel. It was estimated that the average distance covered in each car trip in 1994 was 10 km (Union Routière de France (URF), 1998).

2. EDF, which is administered under state supervision, ${ }^{33}$ relies on the world's most advanced use of nuclear power. Nuclear power plants supplying roughly $75 \%$ of the country's electricity emit the least amount of pollutants compared with other energy resources. This means that France stands to benefit the most from replacing ICEVs with EVs in terms of air quality ${ }^{34}$ (U.S. GAO, 1994).

3. The French government, like most governments in Europe, imposes heavy taxes on gasoline, making alternative fuels such as electricity more attractive to car buyers.

Of these favorable factors, France's utilization of nuclear energy played the most pivotal role in the development of EVs. Although the production of nuclear energy attracts opposition or at least skepticism in most industrialized nations, it still enjoys strong support in France on account of the independence from foreign energy resources it affords.

Although its impact has so far been marginal, the French anti-nuclear movement has remained vehement in its opposition to the government nuclear program. ${ }^{35}$ Therefore, despite the potential environmental benefits of a French EV program, ${ }^{36}$ the majority of environmental groups would support EVs only if the electricity used to power them was produced by non-nuclear power plants. (Parvilliers, 1998; Stephane, 2000; Godinot, 2001). ${ }^{37}$

\footnotetext{
${ }^{33}$ The involvement of the French government in the generation, distribution, and sale of electricity is unique in Western Europe.

${ }^{34}$ In $1998,76.5 \%$ and $12.2 \%$ of electricity were generated by nuclear and hydroelectric power respectively (IEA, 2001a).

${ }^{35}$ Despite massive mobilizations, the French antinuclear movement is not organized in a national lobby as similar movements are in Germany or Sweden. The regulatory process provided virtually no opportunity for public participation and French law did not permit challenges to nuclear-power-site decisions in the courts (Touraine et al., 1980; Nelkin and Pollak, 1981).

${ }^{36}$ Concerns for the unsolved problem of nuclear waste disposal notwithstanding. See Touraine et al. 1980.

${ }^{37}$ Two small environmental groups which had no problem in endorsing nuclear energy sources for EVs: l'Association des Écologistes pour le Nucleaire close at the time to the right wing party Le Front National (Comby, 2002) and Le Mouvement National Lutte pour Environnement affiliated with the Parti Communiste Française (Prince, 2003).
} 
Why France might have not been so serious about EVs

Along with the positive factors encouraging the development of EVs in France, a few factors have hampered it:

1. Car ownership is less diffuse in France than it is in United States and in California. Whereas, in the early 1990 s, there were 1.3 people per vehicle in the United States, there were roughly 2.1 people per passenger car in France (CCFA, 2003). Given the shortcomings of EVs (limited driving range, long refueling time and high price tag), it was unlikely that a household with only one car would have preferred an EV to a more reliable ICEV.

2. The majority of environmental groups gave at best half-hearted support to EVs since they could not summon any enthusiasm for a technology that would reinforce the use of nuclear energy. ${ }^{38}$

3. A successful effort to electrify the fleet of passenger cars would entail substantial tax revenues losses for the French government, as gasoline is taxed at about $80 \%$ whereas electricity is taxed only at about $20 \%$ (IEA, 2001b).

EVs policies in France

The French government has been a key player in the development of EVs so far. The stateowned electric utility EDF, the auto industry (the three automakers Peugeot, Citroën and Renault) as well as local administrative institutions have come together to contribute financially to the development of the electric vehicle industry. An initial protocol, the 1992 Accord-Cadre sur le Developpement du Véhicule Electrique, coordinated by the Ministry of Industry, the Ministry of the Environment, EDF, PSA (a consortium formed by Peugeot and Citroën), Renault and the government agency Groupe Interministériel Véhicules Electriques (GIVE, $1992^{39}$.) considered EVs a timely instrument to reduce pollution and noise in French cities as well as $\mathrm{CO}_{2}$ emissions in French cities (GIVE, 1992). The signatories pledged that within three years the automobile companies would manufacture thousands of EVs and EDF would build the appropriate charging infrastructure. Several government research agencies including ADEME, CNRS, and INRETS were called to participate in the EV program to bring about the protocol's objectives. A more ambitious and formal agreement signed on April 1995 by the Minister of Industry, Renault, PSA, EDF and GIVE defined the modes of engagement of the various partners in the EV program. The 1995 Accord-Cadre aimed for the following by 1999 :

1. 100,000 EVs should be on France's roads

2. Electric vehicles should constitute $5 \%$ of the newly registered vehicles

3. $10 \%$ of public sector vehicle fleets would be electric (GIVE, 1995).

All the goals were voluntary and no penalties were established in the event the goals were not achieved.

To formalize cooperation between the government and the private sector and to provide tangible support for the development of a market for electric vehicles, a decree was signed

\footnotetext{
${ }^{38}$ The skepticism of the French environmental movement towards EV technology is summarized fairly well in an editorial by Les Amis de la Terre (Samuel, 1995).

${ }^{39}$ An ad hoc consortium set up to foster the development of EVs
} 
in May 1995 allocating financial aid $(5,000 \mathrm{FF} \sim \$ 1,050)$ for private citizens who bought electric vehicles. The decree was followed by another protocol in March 1996 that provided more subsidies from $\mathrm{EDF}(10,000 \mathrm{FF} \sim \$ 2,100)$.

At the end of 1996, given the persistence of poor air quality throughout France, the French government passed the Loi sur l'Air et l'Utilisation Rationelle de l'Energie (Law on the Air and the Rational Use of Energy) so as to curb air pollution and foster the rational use of energy. The Loi sur l'Air contained one provision aimed at promoting the development of alternative fuels vehicles. Under title VII, article L. 8-B read:

Within two years from the publication of Law 96-1236 of December 30 1996, the State, the public, national corporations ... when they manage a fleet of at least 20 vehicles must acquire or use, at least, $20 \%$ vehicles powered by electricity, liquid petroleum gas and natural gas. This measure applies to all the automobiles ... with the exception of those which weigh more than 3.5 tons (Journal Officiel de la Republique Française, 1997).

Although the Loi sur l'Air called for the acquisition of alternative fuels vehicles by government agencies, no penalties were imposed on the administrative bodies that failed to equip their fleets with clean vehicles.

In order to make the French public aware of the benefits of electric cars, French authorities set up several EV rental programs to alter the way people use vehicles in urban areas and foster car-sharing where a fleet of vehicles is used by multiple customers. ${ }^{40}$ Praxitèle, the most ambitious of these programs, was started in 1997 in the town of Saint-Quentin en Yvelines on the periphery of Paris. Launched by a consortium of industrial groups (including Renault, EDF, and Dassault) and two research institutes (INRIA and INRETS), Praxitèle aimed at providing French citizens with the mobility, comfort and independence of private car ownership as well as with the benefits of public transit. At Saint-Quentin en Yvelines fifty electric Renault Clios were available in strategic places (parking areas near train and bus stations) for multiple users on a "use it and leave it" principle. Customers had access to the Clios by means of a special magnetic card and paid for the vehicle only when they were using it and not when it was parked (Parent, 1997). Praxitèle closed its operations in June 1999 as it was not considered profitable by the automakers (Parent, 2000). ${ }^{41}$

By the end of 2002, more than 7,500 EVs were circulating in France, far less than 100, 000 goal set in the 1995 Accord-cadre, but still more than any other industrialized country. ${ }^{42}$ In contrast to California's 50\%, in France more than $90 \%$ of all the EVs were used in fleets of municipalities and utilities, bearing out the intention of the government to strengthen EV

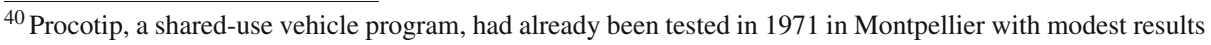
(Benezra, 1995).

${ }^{41}$ After an experimental phase initiated in 1993, the city of La Rochelle established in 1999 LISELEC, another EV car-sharing project that remains active (Benezra, 1995; Hoogma and Simon, 1998). A notable impulse towards EV development in La Rochelle was the personal involvement of the late Michel Crépeau the city mayor and former Minister of the Environment (1981-1984). After PSA shut down a factory in the region in the early 1980s, Crépeau strived to make La Rochelle an industrial center for EV technology with the dual aims of cleaning the air and reducing unemployment (Pasquet, 1996; Hoogma and Simon, 1998). Similar car-sharing programs have been set up in several US cities (Shaheen and Meyn, 2002).

${ }^{42}$ At the end of 2002 there were about 3,500 EVs in the rest of Europe (GIVE, 2003)

Springer
} 
policies by means of public procurement programs (Agence de l'Environnement et de la Maîtrise de l'Energie (ADEME), 2001).

By 1995, Renault presented the Next, a hybrid vehicle prototype ${ }^{43}$, and several French policy analysts have since suggested that HEVs could be a viable technological option to reduce air pollution (Larbaoui, 1998, Badin et al, 2000). However, French legislation and the buying public have barely acknowledged the existence of the new technology. In fact, to date, the only legislative act that has reflected the progress of HEV technology came at the end of 2000: a new provision in the tax code offering a tax rebate of 1,525 euro $(\sim \$ 1,600)$ to customers of HEVs.

Although, they do not deal with alternative fuel vehicles, two other titles of the Loi sur l'Air are germane to the cross-national comparison: title IV, Article 12 stated: "when the alert threshold is trespassed the prefecture takes measures aimed at limiting the intensity and the effects of the pollution on the population. The measures...entail a mechanism of restriction or suspension of the activities concurring to the pollution, including the circulation of vehicles ..."

And title V, Article 28-1, by imposing the adoption of plans de deplacements urban (PDU) (to urban centers with more than 100,000 inhabitants), encouraged a shift to travel demand to more efficient modes: from single occupant vehicle to higher occupancy modes (carpooling and public transit) or to non-motorized modes (pedestrian and bicycle). A revealing expression of the intent to achieve the desired air quality goals by reducing the circulation of private vehicles was exhibited every time the government decreed a special arrêté (ordinance) of circulation alternée (alternate circulation) in Ile-de-France in days when air pollution reached unhealthy levels. Under the circulation alternée policy, cars with odd-numbered license plates were banned from driving on odd days and cars with even-numbered license plates were banned on even days.

A view shared by many in the policy community is illustrated by a case presented at the workshop "Pollutions Atmosphériques: Transports and Santé," organized by the Institut pour un Nouvel Environnement in 2002. Philippe Lameloise, head of Airparif, the agency charged with monitoring air quality in the Paris area, spoke of the recent evolution of CO pollution in two locations in Paris. Over a period of ten years, the levels of CO in Place Victor-Basch have declined dramatically, while on the Champs-Elysées, only a few hundred meters away from Place Victor-Basch, the decline has been notably modest. The speaker noted that Place Victor-Basch has always been in a state of permanent congestion, so that traffic volume cannot increase any further and the emission reductions reflect the technological improvements in automobiles. However, on the Champs Elysées, traffic growth continues offsetting the improvements of the new vehicles. Lameloise concluded that technological advancements alone would not attain satisfactory reductions of air pollution (Hopquin, 2002) ${ }^{44}$ Unfortunately, the actual effectiveness of the PDUs to date, has been disappointing. For instance, the regional plan approved in 2000 for the Ile-de-France called for a $6 \%$ reduction of automobile traffic by 2006 , but by the end of 2001, traffic had increased by $2 \%$ (Hopquin, 2002).

\footnotetext{
${ }^{43}$ In 1996, $R \& D$, Renault's magazine, described the progress on its hybrid prototype in the following terms: "Renault has invented a revolutionary new concept car that was unveiled in 1995, the Next. . The Next has been specially designed with the aim of breaking all fuel economy records. It burns $3.4 \mathrm{~L} / 100 \mathrm{~km}$ of petrol. However attractive such a solution, though, it remains a futuristic dream" (R\&D, 1996).

${ }^{44}$ Note that the president of the Fédération française des automobiles-clubs (which adopted the slogan "Non au PDU, oui à la voiture") has argued that "Pollution will be curbed by means of technological development and not through traffic-volume reductions" (Hopquin, 2002).
} 


\section{Matters of style: Liberalism vs. Dirigisme}

In Section 2 we recalled that two notable components of policy style are (1) a government's approach to problem solving and (2) its relationship with other policy actors. We now discuss how these components differed in France and in California.

\section{California's "round table"}

There are two elements of the American cultural landscape that are relevant to this discussion of EV policies and that set the United States apart from France. To a large extent the industry reaction against the ZEV mandate can be explained in terms of the anti-government sentiment that is prevalent among large segments of American society. Between 1994 and 1996, while the oil and auto industries led their strongest efforts to derail the mandate, Republican members of the newly-elected 104th Congress launched an unprecedented campaign against environmental regulation that was part of a broader crusade against the powers of central government. In those years the belief that the ZEV mandate was a typical example of suspect government interference in the workings of the market was rarely expressed more clearly than at a CARB workshop in December 1995. Sacramento assemblyman Bernie Richter, declared: "... and the other decision that is similar to this (mandate) was made in 1917, at the culmination of the Russian revolution creating the Soviet State, and communizing, and socializing the Russian economy" (Richter, 1995). Richter's over-the-top historical analogy underscores that opposition to the ZEV mandate did not always arise from well-founded skepticism about purported advantages of electric vehicles but rather originated from traditional mistrust of governmental action.

For most of the 1990s, there was intensive national media coverage of the ZEV mandate. Frequently, dailies ran front-page columns and large circulation weeklies published cover stories about electric cars or about the ZEV mandate itself. Mainstream publications covered the subject of EVs in neutral or even sympathetic terms (Woodruff, 1994; Cook, 1996) while conservative publications couched their hostility to the California legislation in explicit antigovernment rhetoric (Taylor III, 1993; McKenna, 1995).

Several environmental groups challenged the CARB's policies whenever they believed that the state agency was caving in to the pressures of the automakers and oil industry (Kasnitz and Maschke, 1996; Heavner, 2000). Throughout the 1990s, many of these groups suspected that the state agency had been "captured" by the oil and automobile interests while the latter claimed that, on the contrary, the CARB had been unduly influenced by the environmental lobby. Thus, the CARB, the industry and environmental groups remained locked in a confrontational relationship fueled by mutual mistrust.

Substantial public participation in the workshops organized by the CARB attests to the pluralistic nature of the American decision-making process. Under the pluralist model, the policy agenda was accessible to all organized interests. Ideally, a just public interest equilibrium should have emerged out of the competition of various policy claims. However, the process was characterized by untrammeled competition between interest groups deeply suspicious of each other, by recourse to the courts and intensive use of lobbying strategies, and by mistrust and open conflict. The continued revisions of the mandate not only reflect the difficulty of developing a new pollution-control technology, but also suggest the perils encountered in a policy arena where the CARB was forced into endless brokering among various interest groups. 
A project that was not grand enough

What characterized the French EV industry in the 1990s was the heavy involvement of the central government, confirming France's penchant for dirigisme, the tradition of strong state intervention actively engaged in subsidizing and protecting certain industrial enterprises. ${ }^{45}$ In fact, the development of EV technology in France can be seen as an example of French industrial policy in action based on the cordial relationship policymakers maintain with the business sector. The French government designed and carried out EV policies in close consultation with automakers without provoking any outcry from them or from any other interest group. The traditional familiarity between businessmen and government officials fostered the development of a shared ethos concerning the main tenets of the EV policy thereby reducing the risk of confrontations. The government upheld its central role long after it had passed the law. Indeed, the Ministry of the Environment set up the Conseil National de L'Air, a study group whose goal was to assess the effectiveness of the Loi sur L'air. In the Conseil's report, the Minister Corinne Lepage admitted that the Loi sur l'Air could have been much more stringent had it not been for the pressures of oil and automobile companies (CNA, 2001) ${ }^{46}$ The contributions to the debate on EV technology in the media as well as in academic and research circles lacked the ideological intensity that characterized the American scene. This is understandable given that the French EV regulations were not nearly as stringent and binding as those adopted in California. Nevertheless, even mildly critical technology assessments were practically absent. The vast majority of technical reports produced (by and large in government research institutes) throughout the 1990s accepted the premise that EVs were a viable and cost-effective technology capable of achieving the goals indicated in the government documents (Clip 1994; Lamure, 1996; CIVP, 2000; Clip, 2001). ${ }^{47}$

The American pluralist model has always been aesthetically as well as politically distasteful to the French as it suggests a permanent state of conflict, compromise and expediency. In contrast to American faith in the virtues of pluralism and open access to the policymaking process, French technocrats display a Cartesian belief in reason and planning and believe that market forces do not necessarily produce a socially optimal outcome without the close supervision of the state. Several scholars have concluded, approvingly, that France is moving away from its dirigiste model (Schmidt, 1996; Levy, 1996; Mustar and Laredo, 2002). Although France is indisputably shedding aspects of its heritage, the country has not, as far as the EV industry is concerned, abandoned its dirigiste model just yet. ${ }^{48}$ Much of the interaction between government and business, the discussions, the meetings and the consultations took place without any need to resort to legislative action. Therefore the process was characterized by a tendency to conduct policymaking activity behind closed doors, free of public scrutiny (Lepage, 2003). Given the cooperative atmosphere between government and business, it is hardly surprising that the latter did not take a public stance against

\footnotetext{
${ }^{45}$ See Shoenfield, 1965 and Crozier, 1970 for two eloquent analyses of the nature of the dirigiste model.

${ }^{46}$ On the pressures exerted by automakers to weaken the air pollution legislation see also Lepage, 1998.

${ }^{47}$ A rare and notable exception is a cost-benefit analysis that concluded: "the cost of air pollution is not enough to give EV a clear advantage against all conventional cars, even in Paris" (Funk and Rabl, 1999).

${ }^{48}$ At least two forces are weakening the twin traditions of Colbertisme and dirigisme: on the one hand, the regulatory competence that once rested with national governments is increasingly shifting towards the European Union (Bailey, 1997) and on the other, the formation of new transnational business alliances (see, in the automobile sector, the agreements between leading Japanese firms like Nissan and Toyota with national automakers) (Kewley, 2002).
} 
the former. Indeed, no interest group claimed that EV technology was ineffective to curb air pollution, let alone challenged the legislation in public or in the courts. In this respect, France provided a clear alternative model to the litigious approach existing in the United States. ${ }^{49}$

Another important element that distinguished the development of the French EV policies from its Californian counterpart was the weak role played by environmental groups. There are two major reasons for this. Although French culture can claim in J.J. Rousseau the first modern thinker who planted the seeds of modern green philosophy, the level of environmental awareness in France is lower than that in the United States. In the institutional arena, the Ministry of the Environment created in 1971 had to struggle to maintain an independent identity from other more powerful ministries (in particular the Ministry of Transport, the Ministry of the Industry and the Ministry of Energy) and has often succumbed to them when confronted with policies that opposed their interests. ${ }^{50}$ And, though in 1995 , a new law empowered environmental groups by giving them a formal venue in which to influence the decision-making process, the level of mobilization remains far weaker than it is in most northern European countries and in the United States (Hayes, 2002; Szarka, 2002). Therefore, although in the mid 1990s the exacerbation of air pollution and congestion in most metropolitan areas increased the level of environmental activism, environmental organizations, by their own admission, have played only a marginal role in the decisionmaking process, especially that which led to the Loi sur l'Air (Godinot, 2001; Lefetey, 2001; Rebelle, 2001). Even though there is a multitude of associations that advance environmental issues, few have a national scope and all suffer from a chronic lack of financial resources (Szarka, 2002). Additionally, France's fragmented environmental movement has played only a small role in forming policies intended to control urban air pollution, in part because few if any of the major environmental groups can afford paid staff to track a thorny issue such as transportation (Lefetey, 2001). Ultimately, the evolution of EV policies has reflected the traditional view that the state is the principal and often the sole guarantor of the public good and that interest groups are almost superfluous and certainly less legitimate than the government. $^{51}$

\section{The technological dimension of policy styles}

Policy styles have dimensions that go beyond a government's relationship with other policy actors. National cultures influence attitudes toward technology and these, in turn, can affect the features of policy formulation. If the ZEV mandate was predicated on pervasive American technological optimism, French efforts at promoting a national EV industry suggest that the United States does not have a monopoly on technological innovation and know-how. France has a strong record of technological achievements in the transport sector such as high-speed trains (train à grande vitesse: TGV), civilian aircraft (Caravelle), as well as in telecommunications (the Minitel system) and the nuclear industry. ${ }^{52}$ However, whereas utilitarian enthusiasm drives technology development in the United States, French technological

\footnotetext{
${ }^{49}$ French institutional arrangements discourage citizens from solving social problems by means of litigation and the symbiotic relationship between the French government and industry makes litigation very rare (Jacob et al., 1996).

${ }^{50}$ For a recent view of the weakness of the Ministry of the Environment see Morand-Deviller, 1990.

${ }^{51}$ See Baumgartner, 1996 for an elucidation of this point.

${ }^{52}$ Even those achievements have been subject to sharp criticism. See Salomon, 1986.

Springer
} 
prowess is driven by a different rationale: even when they are consumer oriented, technological programs in France often serve to advance a national agenda. ${ }^{53}$ In this respect, nuclear reactors, the TGVs and the Concordes have continued the tradition of Colbert's grands projets, where technological achievements blend with political purposes ${ }^{54}$ Developed and operated by state companies, these programs aim to address a particular problem (boost an ailing electronics industry, reduce dependence on foreign oil, develop fast transportation to and from Paris) but were also designed to enhance France's international prestige. At stake in every grand projet was la grandeur of France. They served to build up French national pride and bring the nation together. ${ }^{55}$ Ultimately, the EV technology program, pursued without the conviction of other grand projets, was a strategy designed to affirm French supremacy in advanced automotive technology and to find an outlet for the country's considerable excess capacity of nuclear power (IEA, 1994; Weber and Hoogma, 1998).

\section{The ZEV mandate and the allure of technology}

In California national pride was not an issue. Faced with the difficult problem of cleaning up the foul air of the cities of California, the CARB proposed an ambitious program that relied exclusively on technological improvements. The LEV program did not contemplate any action to induce Californians to drive less. The CARB's policy choices have been consistent with a regulatory tradition in which policymakers have not favored the application of land-use planning, demand travel management and fuel tax policies as means to reduce automobile emissions. In the transportation sector there has been a clear preference for technology standards within the framework of command and control regulations while at the same time large investments in highway infrastructure combined with zoning rules effectively enabled and accelerated the phenomenon of suburbanization and urban sprawl.

This does not mean that the CARB has not recognized the link between land-use planning and the benefits of alternative strategies to curb automobile emissions. In the 1990s, the Transportation Strategies Group at CARB sponsored several studies that highlighted the linkages between air quality benefits, land use and demand travel management strategies acknowledging that increasing public transit ridership and higher residential densities would assist in the long-term improvement and maintenance of California's air quality (CARB, 1997). However, as the former chief manager of the group acknowledged, when it comes to design programs to clean the air in California's cities, the CARB's priorities lie elsewhere (Geraghty, 1998). A speech made in 1998 by J.D. Dunlap, then CARB chairman, provides some insight into those priorities:

Since the early 1950s, when the connection between motor vehicles and smog was established, we've had a clear choice: We can either tell the automakers to make cleaner

\footnotetext{
${ }^{53}$ France's strength lies in promoting those technological projects (such as fast trains, nuclear power, the Concorde jet) sponsored by the government and intended for public use rather than private ownership. In contrast, in the United States technological consumer-oriented products find greater favor.

${ }^{54}$ To appreciate how grand technological projects, in particular the nuclear energy program, served to define the French national identity in the second half of the twentieth century, see Hecht, 1998.

55 There are several historical accounts that show how even unsuccessful projects (cf. the Concorde airplane) tend, by and large, to receive quasi-unanimous approval. See Bess, 2003. This is largely because citizen groups are weak and the state is still perceived as the guarantor of the national interest. In contrast, we have seen that American national pride does not necessarily coalesce around technological projects. In fact in the US, where civil society is robust but not necessarily consensus-oriented, technological fixes (cf. Prozac, SDI, EVs) can divide rather than unite the nation.
} 
cars, or we tell Californians not to drive - and we're not going to tell Californians not to drive (Dunlap, 1998).

In the vision for a clean-air future articulated by Dunlap there appears to be scant room for land-use planning or public transit policies. ${ }^{56}$ This view of the options available to improve air quality is endorsed by many transportation experts and policy analysts. At the 1995 Asilomar Conference on Sustainable Transportation Energy Strategies, a group of experts reached this conclusion:

The issues raised in the wrap-up session lead some of us to conclude that real progress in achieving sustainable transportation will have to be based on very good and nearly transparent technologies. (Transparent, in this case, refers to technologies that would involve no change in consumer perceptions and behavior.) (McNutt, Fulton and Greene, 1997) (emphasis added).

In the same year, Daniel Sperling, an academic who has often written in support of EVs, stated "It is almost impossible to imagine a scenario in which public transit as we know it in the United States would significantly expand its role in passenger travel. Conventional transit is ill suited to contemporary suburban land use patterns, and all trends... suggest that suburbanization is unlikely to be reversed" (Sperling, 1995). Dunlap reflects the expectations of many other policy analysts when he expressed a strong reluctance to employ measures that would constrain the mobility of the American driver. Fiscal instruments (gasoline taxes), travel demand management policies (carpooling, high occupancy lanes) and a shift to public transit, which can be perceived as unbearable restrictions on individual freedom of choice, have met with strong resistance even when they have enjoyed some measure of success. Certainly, any policymaker attempting to curb private passenger car demand would face a daunting task. Decades of sprawl have marginalized public transport systems, which are generally inefficient in areas of low population densities. The demand for private passenger cars and low fuel prices has become so entrenched that policymakers may be unable to reverse the trend.

The United States is a society that prizes individualism and distrusts government interference in public affairs. Since laissez-faire beliefs exert great influence on the public discourse and on the political agenda, environmental regulations which stimulate technological solutions and do not threaten citizens' lifestyles or core American values look very appealing to many policymakers. ${ }^{57}$ As the ultimate technological fix, ZEVs do not call for efforts to change consumer behavior as would be necessary if demand travel management or public transit policies were implemented. ${ }^{58}$ And policymakers in California know full well that it would be very difficult to pull citizens out of their cars.

\footnotetext{
${ }^{56}$ To be sure, the California legislature has not given CARB authority over moving people and goods on its roads and highways. This authority remains with the State Department of Transportation as well as with regional, county and city transportation agencies (Kopp, 1997). However, the overall effect is that as a state agency with great authority over drafting policies to reduce air pollution, CARB can send recommendations to these bodies, which in turn are obliged to give them strong consideration.

${ }^{57}$ The influence of free-market beliefs in the U.S is often more rhetorical than real. Indeed, in many areas of consumer, environmental and safety regulation, US government agencies have traditionally used command and control instruments that are far more stringent and intrusive than the market-based tools customarily employed in Europe. See Vogel, 2003.

${ }^{58}$ Some scholars contend that driving EVs can change peoples' driving habits (for instance, due to the EVs' limited range, drivers tend to plan trips more carefully) as well as general attitudes toward transportation issues. For a discussion of the civic values of EV technology see Brown, 2001.
} 
The CARB's penchant for technological solutions to clean the air also reflects Americans' strong faith in the ability of technology to solve society's problems. To be sure, the attitude of Americans toward technology is complex and has changed over the years. Perhaps most dramatically, after the advent of nuclear weapons it became increasingly difficult to view technology solely as a benign agent of change. But overall, Americans remain in awe of technological progress. ${ }^{59}$ This special affinity for technology is revealed by the remarkable degree of attention that the ZEV regulation has received in the press and among policymakers and industrial entrepreneurs. It would be difficult to dispute the positive impacts of technological advancement for private passenger cars. Yet, the effects of an intense faith in the promise of automobile technology are evident in Southern California. Although over the past 25 years California has been recognized as the world leader in pioneering policies to curb automobile emissions, many areas of the state are still affected by the foulest air in the nation. ${ }^{60}$ Sophisticated technological advancements have so far proved insufficient to offset the huge growth of the private car fleet and its stagnant fuel economy.

Even though it has not turned out to be a panacea for the health problems created by passenger cars, technological innovation is a strategic and crucial determinant in improving environmental performance. In this respect, the ZEV mandate was successful, since it proved to be sufficiently flexible to encourage and foster the development of hybrid vehicle technology. At first, CARB's interest in hybrid electric vehicles (HEVs) was governed by the necessity to extend the range of EVs, but by the late 1990s, it was clear that hybrids provided substantial improvements in fuel efficiency, could reduce emissions of NOx and $\mathrm{CO}_{2}$ and could have a much broader market appeal than EVs (O'Dell, 2000; Easterbrook, 2000).

Honda and Toyota, two of the major automakers active in the California market, compelled by the ZEV mandate to develop their capabilities to produce cars with electric drive trains and batteries, viewed hybrid technology not as a short-term solution, but as a long-lasting technological option to meet increasingly stringent standards while creating and exploiting a profitable new passenger vehicle market. Carmakers in France, having invested for decades in diesel engine technology, have shown little interest in hybrid technology and, except for moderate tax deductions, there is no regulatory strategy designed to promote HEVs (Kliesch and Langer, 2003). Thus, although, the price of gasoline is at least 2.5 times higher than in the United States, theoretically making the fuel-economy virtues of hybrid technology more attractive to French drivers than to Americans, HEVs have yet to attract a significant number of customers (cfr. Table 5).

The importance of HEVs lies not only in improved fuel economy and significant reduction of $\mathrm{CO}_{2}$ and other air pollutants, but also in being the first realistic technological option for private transport that does not rely exclusively on gasoline. HEVs, the California's mandate's most recent technological outcome, may not be what CARB had originally envisioned, but they are nevertheless a striking development in automotive technology.

\footnotetext{
${ }^{59}$ There is evidence of this in many contexts of American life. Popular culture provides many examples: the popularity of magazines (Popular Mechanics, Popular Science, etc.) that probe the minutiae of technological advancement and films like Apollo 13 in which technological ingenuity - a distinctive national virtue provides the ability to overcome mortal challenge. For a scrutiny and skeptical views of American technological optimism see Marx, 1987; Nye, 1994 and Segal, 1994.

${ }^{60}$ Ozone levels in California have dropped significantly throughout the 1990 s whereas progress in other regions of the U.S. has not been as dramatic. Nevertheless, in 2002 the 16 most severe violations of the EPA ozone 1-hour standard were all in California (EPA, 2003b).
} 
Table 5 Number of hybrid vehicles registered in California, the USA and France: 1999-2005

\begin{tabular}{lccc}
\hline & \multicolumn{3}{c}{ Registered hybrid vehicles } \\
\cline { 2 - 4 } Year & California & USA & France \\
\hline 2000 & 1,000 & 9,350 & $/$ \\
2001 & 4,000 & 20,287 & $/$ \\
2002 & 6,000 & 35,853 & 51 \\
2003 & 12,500 & 47,525 & 15 \\
2004 & $25,000^{\text {a }}$ & 88,000 & 604 \\
$2005^{\text {b }}$ & 38,000 & 117,210 & 3,000 \\
Total & 86,500 & 318,225 & 3,670 \\
\hline
\end{tabular}

Sources: RL Polk \& Co, 2005; DOE, 2002a (USA); Eley, 2005 and authors' estimates, (California); Toyota, 2005 (France)

${ }^{a}$ Only AT-PZEV hybrids

${ }^{\mathrm{b}}$ Figures through June 2005

\section{The persistence of policy styles}

The patterns of policy formulation, implementation and outcome in the two countries revealed many sharp differences and a few similarities. The original policy goal was the same: reducing automobile emissions. Two other important similarities stood out: in the early 1990s, policymakers, in both California and France thought that EVs could play a significant role in achieving this policy goal and, by the year 2001, EV technology was deemed not yet mature. However, the policy instruments and policy styles in California and in France were markedly different. Our findings are comparable to those of Lundqvist who analyzed Swedish and US clean air policies between the late 1960s and 1970s. Lundqvist wrote (1980) "Undisturbed by citizen suits and court orders,... administrators could engage in negotiations with polluters to find an acceptable formula for policy implementation. Furthermore these negotiations were not constrained by any legally prescribed standards or compliance deadlines." Although this was written about Sweden, the quote also accurately describes the EV policy process in France. The French EV strategy was part of an established policy heritage composed of the usual ingredients: dirigisme, voluntary agreements, friendly negotiations and little disagreement about the merits of EV technology, limited ability of non-industry groups to participate in the regulatory process and no recourse to the courts. In contrast, the ZEV mandate is indicative of the American regulatory approach composed of ambitious technology-forcing, binding targets, science-based adversarialism, openness of the policy process to citizens' and interest groups and the heavy role of judicial review. This litigious regulatory culture that characterized the EV policies in California has a distinct American flavor and is highly uncharacteristic of France.

The transatlantic divide inferred by Lundqvist remains intact 20 years later in the EV case. It is natural therefore to venture that national policy styles matter now as they mattered then; they are stable and well entrenched "standard operating procedures" largely immune to the forces of an increasingly integrating global economy. Policy styles reflect deep-rooted national political and social cultures and there is no reason to expect them to change over a relatively short period of time. However, if we look at the recent history of environmental regulations on both sides of the Atlantic, things are somewhat more complicated and the lack of policy convergence in our case study may be an exception to current trends. It is unanimously recognized that from the late 1960s to the mid 1980s in critical areas such 
as air and water quality regulation, the United States set the most stringent standards and fostered the most effective technological innovation. It is also true that since the early 1990s, environmental standards in many European countries and in Japan have become progressively more strict (Schreurs, 2003). Indeed, recently Vogel argued that, since the late 1980s, the US and Europe have "traded places." ${ }^{61}$ In other words, whereas in the 1970s and 1980s, the US provided strong leadership in environmental policy by adopting strict and innovative legislation, over the last 15 years, European countries have taken the lead (Vogel, 2003). Our study demonstrates that the French and the California experiences with EV policies are exceptions to this trend reversal. ${ }^{62}$ This anomalous situation suggests that the policy style framework must be handled with care. First, there is considerable policy variance across industrial sectors within each country (Kitschelt, 1991), and in the United States different policy outcomes occur at the national and state levels. Additionally, the United States employs different approaches to regulating emissions from mobile and fixed sources; that is, it regulates mobile sources largely by command and control, and fixed sources by market methods. ${ }^{63}$ Regarding styles, we should recall that France demonstrated far greater resolve when it developed postwar high tech engineering programs such as the Ariane space-rocket, the TGV, the Minitel and nuclear power plants than when it pursued EV polices in the 1990s (Cohen, 1992). Indeed, in 1982, Hayward observed that France could employ an heroic policy style, that had "a potential for far-sighted planning and a propensity to impose its will. ..., as well as a hum-drum style characterized by excessive negotiation and compromise (Hayward, 1982). France's varying disposition toward science and technology policies demonstrate that sometimes the appropriate locus for examining policy style is not the nation-state but rather the sector or even the agency (Freeman, 1985). However, our comparative exercise is in accord with past studies of environmental, health and safety policies indicating that national styles do exist and can arguably be attributed to the influence of the cultural milieus in which policies are formulated (Lundqvist, 1980; Badaracco, 1985; Vogel, 1986; Brickman et al., 1985; Weber and Hoogma, 1998).

\section{Conclusions}

Throughout the 1990s California and France each responded to concerns about urban air quality by making substantial efforts to promote the use of EVs. It is clear that these efforts had an effect; most of the world's current stock of EVs can be found in these two places. To date, however, the direct effect has been small; only a few thousand vehicles have been sold in

\footnotetext{
${ }^{61}$ A well known illustration of this flip-flop is the US position on climate change. Despite the US role as the world's leading producer of greenhouse gas emissions on an absolute and per-capita basis, the US Senate has not ratified the Kyoto Protocol and the Clinton and G.W. Bush administrations (through 2005) have refrained from taking any action that would force the private sector to curb $\mathrm{CO}_{2}$ emissions and instead recommended only voluntary programs to limit greenhouse gas emissions.

${ }^{62}$ California is not the US, but it is the most populous state in the country, its economy is the largest among US states and, most importantly, it has been the pace setter in environmental regulation domestically for several decades. California's proactive, adversarial style is not limited to the ZEV mandate. For instance, in 2003, instead of following the climate change policies of the federal government, California policymakers enacted legislation (bill A.B. 1493) which required CARB to develop regulations that achieve the maximum feasible and cost-effective reduction of greenhouse gas emissions from motor vehicles. "In June 2005, the governor of California signed an executive order calling for a slowdown of emissions by 2010 to the level recorded for the year 2000 (Sahagun, 2005).

${ }^{63}$ In the 1990s, the US used a sulfur trading system, i.e., a market-based approach, to curb sulfur dioxide emissions.
} 
each country. The indirect effects, however, may prove to be much larger. The pathways taken by California and France were very different. California, acting through the CARB, took an active regulatory role that was explicitly and very publicly technology forcing. The response was also very public; there were lawsuits and advertising campaigns both for and against the mandates; but even as it complained, the automotive industry put forth a very extensive research and development effort on batteries, fuel cells, and electric drive trains. While the CARB maintained an aggressive posture, it continued to monitor the suitability of available EV technology and modified its mandate accordingly. The emphasis was on development of vehicles that consumers would accept. Revisions to the mandate reflected the CARB's recognition that EVs were not yet viable and allowed the agency to steer a technological trajectory which also served to catalyze alternative developments, notably hybrid vehicles which are far more popular than EVs and new progress toward vehicles powered by fuel cells.

The establishment of strict standards and flexible implementation timetables coupled with the imposition of penalties and the commitment by a few major automakers to substantial $\mathrm{R} \& \mathrm{D}$ and commercial programs to reduce emissions triggered a critical new phase of technological progress. In this respect, the CARB's mandate represents a watershed in the shift in road transportation from petroleum to electricity, yielding the accompanying benefits of reductions in air pollutants (including greenhouse gases) and fuel-economy improvements.

In contrast with the American process, the French EV industrial path was utterly guided from above with negligible public dialogue and controversy. While significant portions of American society engaged in a discussion of the new technology, fiercely assessing its merits and drawbacks, the French public, the media and analysts remained comparatively aloof, showing only a tepid interest in EVs. Rather than indicating the development of an authentic national consensus about the effectiveness of EVs to reduce automobile emissions, the absence of controversy about EVs in France signaled a deficit of public participation and accountability. The programs and the legislation developed in France to electrify a fraction of the national car fleet were anything but a grand projet and did not amount to industrial policy, although for several years they had the pretense of being one. France has so far shown little interest in the hybrid technology that has emerged from EV research and development.

What are the lessons from this comparative study? Technology forcing-a regulatory strategy apt for a society inspired by the promise of technological solutions-can work and can lead to substantial and important new innovations and capabilities. But the consequent technological evolution may follow unpredictable pathways, yielding unexpected results. Industrial policy also can work and has worked in other settings in France (and elsewhere), but the lackluster development of electric drive-train technology demonstrates that the success of industrial policy requires a firm institutional commitment, including, for example, the catalysis of markets or commitments to procure EVs for public fleets.

This study confirms also that despite growing integration of markets and economic policies, industrialized nations retain distinctly different policy styles. These different styles can influence the type of solution adopted to solve specific environmental problems. For example, in California, environmental policy was largely driven by technological development which fostered the emergence of hybrid vehicles. Thus, when looking at the way policy styles shape environmental regulatory strategies, it is crucial to consider not only the patterns of interaction between policy actors, the particular modes of policy contestation and the degree of government's responsiveness, but also society's attitudes towards technology. Indeed, one aspect of the policy divergence analyzed in this article deserves particular attention: France and California exhibit subtle but significant differences in public attitudes toward technology. 
In the United States, technological solutions are championed over solutions that require behavioral change. In France, technological advances are strongly related to national prestige and reflect a compromise between government and industry; technology it is still a form of cultural elitism.

Acknowledgements The authors thank Daniel Becker, Julie Becker, Michael Bess, Tom Cackette, Krista Eley, Olivier Fillieule, Eric Fujita, Andy Frank, Sylvain Krummenacher, Sebastien Noguès, Michel Parent, Nicolas Pasquet and the late Victor Wouk for discussions and for providing useful data. We also thank Stéphane Biscaglia, Tom Evashenk, Remco Hoogma, Joseph Szarka and David Vogel for critical comments on earlier drafts. We gratefully acknowledge an anonymous reviewer for helping to strengthen considerably the paper. David Calef is especially grateful to Neer Asherie, Josephine Roccuzzo and the late Jeanne X. Kasperson for their encouragement and valuable advice.

\section{References}

Agence de l'Environnement et de la Maîtrise de l'Energie (ADEME, 2001). Equipement des Flottes Publiques en Véhicules Propres. Présentation du 3 Avril.

Ashford, N.A., Heaton, G.R., Maxwell, \& McCleary-Jones, J. (1982). Environmental regulation of the automobile. Report CPA-82-1, Center for Policy Alternatives, Massachusetts Institute of Technology.

Ashford, N.A., Ayers, C., \& Stone, R.F. (1985). Using regulation to change the market for innovation. Harvard Environmental Law Review, 9, 419-466.

Association of International Automobile Manufacturers Inc, v. Commissioner, Massachusetts. (AIAM, 2000). Department of Environmental Protection. No. 99-2245.

Airparif. (2003). Historique-statistiques. Available on: http://www.airparif.asso.fr/.

American Automobile Manufacturers Association. (1994). American Automobile Manufacturers Association v. Massachusetts D.E.P., 31 F.3d, 18 First Circuit.

American Automobile Manufacturers Association. (1995). Request for Proposal. Washington, DC: AAMA.

American Automobile Manufacturers Association v. Commissioner. (AAMA, 1998). No. 93-10799-ADM. Environmental Law Reporter 3-98.

Badaracco, J. (1985). Loading the Dice: A Five-Country Study of Vinyl Chloride Regulation, Boston: Harvard Business School Press.

Badin, F., Janneret, F., Harel, F., \& Trigui, R. (2000). Véhicules hybrides. Paper presented at the conference Prop-Elec 2000, La Rochelle Septembre.

Bailey, P. (1997). The implementation of EU environmental policy in France. In C. Knill (Ed.), The Impact of National Administrative Traditions on the Implementation of EU Environmental Policy. Florence: European University Institute.

Baumgartner, F.R. (1996). Public Interest Groups in France and in the United States. Governance, 9, 1-22, January.

Beder, S. (1998). Public Relations' Role in Manufacturing Artificial Grass Roots Coalitions. Public Relations Quarterly, 43, 21-23.

Benezra, C. (1995). Les Vehicules Electriques En Libre Service: Politique Des Villes Et Strategies Des Acteurs. These ss. dir. JJ Chanaron et E. de Banville, Université Pierre Mendes France-Grenoble.

Bess, M. (2003). The Light-Green Society. Ecology and Technological Modernity in France, 1960-2000, Chicago: University of Chicago Press.

Brickman, R., Jasanoff, S., \& Thomas, I. (1995). Controlling Chemicals: The Politics of Regulation in Europe and the U.S. Ithaca, NY: Cornell University Press.

Brief for the United States as Amicus Curiae of Central Valley Chrysler-Plymouth, INC. et al. V. Michael P. Kenny. No. 02-16395.

Brief for California Motor Car Dealers Association as Amicus Curiae of Central Valley Chrysler-Plymouth, INC. et al. V. Michael P. Kenny. No. 02-16395.

Brown, M.B. (2001). The Civic Shaping of Technology: California's Electric Vehicle Program. Science, Technology and Human Values, 26, 56-81.

CARB. (1990). Proposed Regulations for Low-Emission Vehicles and Clean Fuels. Staff Report. Sacramento, CA.

CARB. (1995). Proposed Amendments to the Low Emission Vehicle Regulation to Add an Equivalent Zero Emission Vehicle (EZEV) Standard and Allow Zero Emission Vehicle Credit for Hybrid-Electric Vehicles. Sacramento, CA. 
CARB. (1996a). Mail Out \# 96-06. Errata Notice for Zero-Emission Vehicle Staff Report, Table 2. Proposed Multiple ZEV Credits-Range. Sacramento, CA.

CARB. (1996b). Proposed Amendments to the Low-Emission Vehicle Regulations to Add an Equivalent Zero Emission Vehicle Standard. Sacramento, CA.

CARB. (1997). The Land Use-Air Quality Linkage. How Land Use and Transportation Affect Air Quality. Sacramento, CA.

CARB. (1998a). Summary of Proposed Amendments to California's Low Emission Vehicle Regulations "LEV II". Sacramento, CA.

CARB. (1998b). Proposed Amendments to California Exhaust Evaporative and Refueling Emission Standards and Test Procedures for Passenger Cars, Light-Duty Trucks and Medium-Duty Vehicles "LEV II" and Proposed Amendments to California Motor Vehicle Certification, Assembly Line and In-Use Test requirements “CAP 2000”, Preliminary Draft Staff Report. Sacramento, CA.

CARB. (1999). California Exhaust Emission Standards and Test Procedures for 2003 and Subsequent Model Zero-Emission Vehicles, and 2001 and Subsequent Model Hybrid Electric Vehicles, in the Passenger Cars, Light-Duty Truck and Medium-Duty Vehicle Classes. Sacramento, CA.

CARB. (2001). ARB Fact Sheet: Zero Emission Vehicles Program Changes. Sacramento, CA.

CARB. (2002). The 2002 California Almanac of Emissions and Air Quality. Sacramento, CA.

CARB. (2005). The 2005 California Almanac of Emissions and Air Quality. Sacramento, CA.

California Department of Transportation (Caltrans). (2001). California Motor Vehicle Stock, Travel and Fuel Forecast, November.

California Department of Transportation (Caltrans). (2004). California Motor Vehicle Stock, Travel and Fuel Forecast, November.

California Energy Commission, California Electrical Energy Generation 1992 to 2002. Available at http://www.energy.ca.gov/html/calif_energy_facts.html. Accessed on February 3, 2003.

Centre Interprofessionel Technique d'Etudes de la Pollution Atmosphérique. (CITEPA, 1998). Inventaire des Emissions de polluants Atmospheriques en France - Series Sectorielles et Analyses Etendues.

Centre Interprofessionel Technique d'Etudes de la Pollution Atmosphérique. (CITEPA, 2005). Inventaire des Emissions de polluants Atmospheriques en France - Series Sectorielles et Analyses Etendues.

Club d'ingénierie prospective énergie et environnement (CLIP, 1994). Les Cahiers du Clip no 2 : Les enjeux environnementaux de la pénétration du véhicule électrique en Europe, Mai.

Club d'ingénierie prospective énergie et environnement (CLIP, 2001). Les Cahiers du Clip no 13: Le véhicule électrique à l'horizon 2050, Avril.

Cohen, É. (1992). Le Colbertisme "High Tech". Paris: Hachette.

Comité des Constructeurs Français d'Automobiles (CCFA, 2003). Analyse et statistiques. L'industrie Automobile Française.

Comité Interministeriel pour les Véhicules Propres (CIVP, 2000). Véhicules Propres Fonctionnant au GPL, GNV et à l'Electricité: Etat des Filieres et Propositions de Politiques Publiques d'Accompagnement, Avril.

Conseil National de l'Air (CNA, 2001). L'Evaluation de la Mise en Oeuvre de la Loi sur L'Air et L'Utilisation Rationelle de L'Energie du 30 Décembre 1996, Décembre.

Consumer Reports. (2005). CR investigates. Fuel economy: Why you're not getting the MPG you expect. Consumer Reports, 70, 20-25, October.

Cook, W.J. (1996). Look, mom, no gas. U.S. News \& World Report, September 30.

Crozier, M. (1970). La Société Bloquée. Paris: Editions du Seuil.

Daimler Chrysler Corporation et al. v. Erin Crotty, Commissioner, New York State Department of Environmental Conservation Civil Action No. 01-CV-1066. 2002.

Dale, L. (1995). Impacts to the California Economy of Estimated Expenditures on Alternative Fuel Vehicle Programs, Statement delivered at CARB meeting November 8.

De Neufville, R., Connors, S.R., Field III, F.R., Marks, D., Sadoway, D.R., \& Tabors, R.D. (1996). The Electric Car Unplugged. Technology Review, 99, 30-36, January.

Department of Energy. (DOE, 2002). FreedomCAR \& Vehicle Technologies, "Fact \#230 Hybrid Electric Vehicles in the United States", August 19.

Department of Energy. (DOE, 2002a). Fact \#230 hybrid electric vehicles in the United States. In FreedomCAR and Vehicle Technologies.

Department of Energy. (DOE, 2002b). Energy Secretary Abraham Launches FreedomCAR, Replaces PNGV. Available at http://www.energy.gov/HQPress/releases02/janpr/pr02001_v.htm.

Dunlap III, J.D. (1998). Clean Air in California: The Past, Present and Future of Air Quality in the Golden State. Speech given at the Orange County Forum, Irvine by CARB chairman on September 181998 available on http://www.arb.ca.gov/speeches/ocforum.htm. 
Duoba, M., Lohse-Busch, H., \& Bohn, T. (2005). Investigating Vehicle Fuel Economy Robustness of Conventional and Hybrid Electric Vehicles. Paper presented at the EVS-21on April 2-6, 2005.

Easterbrook, G. (2000). Hybrid Vigor. Atlantic Monthly, 286, 5 , 16-18, November.

Electric Utility Week, (1996). California EV Mandate Rolled Back. Justice Dept. Sets Antitrust Probe, April 8, 3-4.

Environmental Protection Agency. (2003a). 2003 Fuel Economy Guide. Available at: http://www.fueleconomy.gov/feg/2001car2tablef.jsp. Accessed on April 19, 2003.

Environmental Protection Agency. (2003b). AirData Monitor Values Report. Available at: http://oaspub.epa.gov/pls/airsdata/ADAQS.monvals. Accessed on November 4, 2003.

Environmental Protection Agency. (2005a). Light-Duty Automotive Technology and Fuel Economy Trends: 1975 through 2005. EPA420-R-05-001.

Environmental Protection Agency. (2005b). Green Vehicle Guide. Available at: http://www.epa.gov/greenvehicles. Accessed on August 20, 2005.

European Commission. (2005). European Union. Energy \& Transport in Figures 2004.

Fagan, K. (1999). Honda Stops Making Fully Electric Car. San Francisco Chronicle, April 30, A1.

Faucheux, R. (1995). The grassroots explosion. Campaign \& Elections, 16, 20-30, December-January.

Ford, A. (1994). Electric Vehicles and the Electric Utility Company, Energy Policy, 22, 555-570.

Freeman, G.P. (1985). National Styles and Policy Sectors: Explaining Structured Variation. Journal of Public Policy, 5, 467-495.

Funk, K., \& Rabl, A. (1999). Electric versus conventional vehicles: Social costs and benefits in France, Transportation Research Part D 4, 397-411.

General Motors. (2002). Letter to EV1 lessees. February 7.

Glover, M. (2000). GM pulls plug on EV. Automotive Engineer, 25, 6, March.

Graebner, L. (1995). Electric Cars: Big Oil, Detroit vs. Big Electric, The Sacramento Business Journal, November 20: 1 .

Grefe, E.A., \& Linsky, M. (1995). The New Corporate Activism: Harnessing the Power of Grassroots Tactics for Your Organization. McGraw-Hill.

Groupe Interministériel Véhicules Electriques. (GIVE, 1992). L’accord-cadre sur le développement du véhicule electrique, 28 Juillet.

Groupe Interministériel Véhicules Electriques. (GIVE, 1995). L'accord-cadre sur le développement du système “véhicules électriques". April 11.

Groupe Interministériel Véhicules Electriques. (GIVE, 2003). Immatriculation de véhicules electriques neufs en France depuis 1993.

Hayes, G. (2002). Environmental Protest and the State in France. Basingstoke: Palgrave.

Hayward, J. (1982). Mobilising private interests in the service of public ambitions: The salient element in the dual French policy style? In J. Richardson (Ed.), Policy Style in Western Europe. London: George Allen \& Unwin.

Heavner, B. (2000). Pollution Politics 2000, California Political Expenditures of the automobile and Oil Industries, 1997-2000, California Public Interest Research Group Charitable Trust.

Hecht, G. (1998). The Radiance of France: Nuclear Power and National Identity after World War II. Cambridge, MA: MIT Press.

Henriksen, G. L., DeLuca, W. H., \& Vissers, D. R. (1994). Advanced Batteries for Electric Vehicles, ChemtTech, 24: 32-38.

Hoffman, G. (1967). Hybrid Power Systems for Vehicles. U.S. Public Health Service Publication 999-Ap-37.

Hoogma, R., \& Simon, B. (1998). The La Rochelle Experiment with Electric Vehicles. MERIT/CIRED and University of Twente.

Hopquin, B. (2002). L'automobile pollue moins, mais est toujours reine en ville. Le Monde, November 28.

Hwang, R.J. (2002). Declaration of Roland J. Hwang in Support of Motion to Intervene by NRDC, Inc. and Production EV Drivers Coalition.

Institut National de la Statistique et des Etudes Economiques. (2004). Tableaux de l'Économie Française Édition 2005-2006. Paris.

International Energy Agency. (IEA, 1994). Electricity supply industry: Structure, ownership and regulation in OECD countries. Paris, OECD.

International Energy Agency. (IEA, 2001a). Energy Policies of IEA Countries, France 2000 Review. International Energy Agency. (IEA, 2001b). Energy Prices \& Taxes, Quarterly Statistics First Quarter.

Jacob, H., Blankenburg, E., Kritzer, H.M., Provine, D.M., \& Sanders, J. (1996). Courts, Law and Politics in Comparative Perspective. New Haven, CT: Yale University Press.

Journal Officiel de la République Française. (1997). Loi no. 96-1236 du Décembre 1996 Sur L'air et L'utilisation Rationelle de L'énergie. 
Joyce, M. (2001). Development in U.S. Alternative Fuel Markets. A Report for the Energy Information Administration. U.S. Department of Energy.

Kagan, R.A. (2001). Adversarial Legalism. The American Way of Law. Cambridge, MA. Harvard University Press.

Kalhammer, F.R., Kozawa, A., Moyer, C.B., \& Owens, B.B. (1995). Electric Vehicles: A Report of the Battery Technology Advisory Panel, Prepared for CARB, El Monte, CA.

Kasnitz, M., \& Maschke, E. (1996). Naughty or Nice - The Grinch Report: No Clean Air For Christmas A Report for Calpirg, Santa Barbara. Ca. Calpirg.

Kelman, S. (1981). Regulating America, Regulating Sweden: A Comparative Study of Occupational Safety and Healthy Policy, Cambridge, MA: MIT Press.

Kewley, S.J. (2002). Toyota's French Connection. Trends in Japanese-European Automotive Relations. London: Royal Institute of International Affairs.

Kitschelt, H. (1991). Industrial governance structures, innovation strategies, and the case of Japan: Sectoral or cross-national comparative analysis? International Organization, 45, 453-493.

Kliesch, J., \& Langer, T. (2003). Deliberating Diesel: Environmental, Technical and Social Factors Affecting Diesel Passenger Vehicle Prospects in the United States, American Council for an Energy-Efficient Economy.

Kopp, Q.L. (1997). California Senator Bill 45. State of California.

Krémer, P. (1995). Des pediatres organisent une étude épidemiologique. Le Monde, November 29.

Lamure, C. (1996). Le véhicule électrique à l'horizon 2004 : Controverses en Californie, prémices d'une bataille mondiale. 2001 Plus, Paris, Ministère de l'équipement, du logement, des transports et du tourisme.

Larbaoui, P. (1998). Le Véhicule Electrique, Une Etape Vers Le Véhicule Hybride, Ou Comment Emergent Les Paradigmes Technologiques. Paper presented at the Rencontres Internationales du Gerpisa, Paris, Palais du Luxembourg, Juin.

La Pierre, B.D. (1977). Technology-Forcing and Federal Environmental Protection Statutes. Iowa Law Review, $62,771-838$.

Lave, L.B., Hendrikson, C.T., \& McMichael, F.C. (1995). Environmental Implications of Electric Vehicles. Science, 268, 993-995.

Lave, L.B., Russell, A.G., Hendrickson, C.T., \& McMichael, F.C. (1996). Battery-powered vehicles: ozone reduction versus lead discharges. Environmental Policy Analysis, 30(9), 402A-407A, September.

Lepage, C. (1998). “On ne peut rien faire Madame le Ministre... ”. Paris: Albin Michel.

Levy, J.D. (1996). The Crisis of Identity of Post-Dirigiste France. French Politics \& Society, 14, 36-44.

Lundqvist, L.J. (1980). The Hare and the Tortoise: Clean Air Policies in the United States and Sweden, Ann Arbour: University of Michigan Press.

MacKenzie, J.J. (1994). The Keys to the Car: Electric and Hydrogen Vehicles for the 21 st Century. Washington, DC: World Resources Institute.

Malakoff, D. (1999). U.S. Supercars: Around the Corner, or Running on Empty? Science, 285, 680-682, July 20.

Mangels, A. (1995). Statement before CARB, November 8.

Marx, L. (1987). Does Improved Technology Mean Progress? Technology Review, 90, 32-41, January.

Maynard, M. (2002). Ford Abandons Venture in Making Electric Cars. New York Times, August 31, C1.

Mazur, A. (1981). The Dynamics of Technical Controversy. Washington, DC: Communication Press.

McKenna, M. (1985). Electric Avenue. National Review, 32-38, May 29.

McNutt, B., Fulton, L., \& Greene, D. (1997). Is Technology Enough? A Synthesis of Views Expressed at the Conference in Transportation, Energy, and the Environment: How Far Can Technology Take Us?, J. DeCicco \& M. Delucchi (Eds.), Washington, DC: American Council for an Energy-Efficient Economy.

Medina, S., Le Tertre, A., Quenel, P. et al. (1994). Évaluation de l'impact de la pollution atmospherique urbaine sur la Santé en Ile-de France:1987-1990 (étude “ERPURS”), Rapport Orsif Observatoire Régional de la Santé d'Ile-de-France, September.

Mobil Corporation. (1995a). Running out of oil? \# 6 of the 'Hidden Price Tags' series published in the New York Times Op-ed page, May 22.

Mobil Corporation. (1995b). Striking a Jurassic spark, \# 7 of the "Hidden Price Tags" series published in Newsweek, June 19.

Morand-Deviller, J. (1990). Le Droit Français de l'Environnement: Progrès, Carences. Revue Française d'Administration Publique, Janvier-Mars, 23, n. 53.

Murphy, K. (2005). To Save on Gasoline, Look Beyond the E.P.A. Sticker. New York Times, C7, October 30.

Mustar, P., \& Larédo, P. (2002). Innovation and research policy in France (1980-2000) or the disappearance of the Colbertist State. Research Policy, 31, 55-72.

MVMA. (1993). Motor Vehicle Manufacturers Association of the U.S., Inc. v. New York State Department of Environmental Conservation, 810 F. Suppl. 1331. 
National Research Council. (1996). Review of the Research Program for the Partnership for a New Generation of Vehicles, Commission on Engineering and Technical Systems, National Academy Press.

Nelkin, D., \& Pollack, M. (1981). The Atom Besieged: Extraparliamentary Dissent in France and West Germany. Cambridge, MA: MIT Press.

Nelkin, D. (1992). Controversy: Politics of Technical Decisions (3rd ed.). Beverly Hills, CA: Sage Publications.

Normand, J. (1995). Les effets sur la santé sont encore mal connus. Le Monde, October 12.

Nye, D.E. (1994). American Technological Sublime. Cambridge, MA: MIT Press.

O’Dell, J. (2000). Part of the Thinking Behind Hybrids: People May Actually Buy Them. Los Angeles Times, February 2, G1.

O’Dell, J. (2002). Car Companies Team Up to Fight State's ZEV Rule. Los Angeles Times, January 23 , G1.

Ogden, J.M. (1999). Prospects for Building a Hydrogen Energy Infrastructure. Annual Review of Energy and Environment, 24, 227-279.

Parent, M. (1997). Development of the Electric Vehicle Market in France: Products and Strategy. Paper presented at the EV-14 Symposium, Orlando, Florida December.

Parrish, M. (1994). Trying to Pull the Plug. Los Angeles Times, April 14, D1.

Pasquet, N. (1996). Principales étapes constitutives d'un réseau technico-économique - Le cas du véhicule électrique à La Rochelle. Mémoire de D.E.A., Ecole Centrale de Paris.

Patel, T. (1995). Paris chokes while officials fiddle. New Scientist, 147, 9, July 29.

Rasul, F. (2001). The Next Big Thing? documentary aired on PBS, January 5.

$R \& D$. (1996). Electric vehicles: Plugging in to the future. 1-9, October.

Richardson, J. (1982). Policy Styles in Western Europe. London: Allen \& Unwin.

Richter, B. (1995). CARB Minutes of December 21, 1995 Meeting.

Riezenman, M.J. (1995). The Search for Better Batteries. IEEE Spectrum, 32, 51-56, May.

R. L. Polk \& Co. (2005). Hybrid Vehicle Registrations.

Sahagun, L. (2005). Gov. Turns Up Heat in Global Warming Fight. Los Angeles Times. July 5, A10.

Salomon, J. (1986). Le gaulois, le cow-boy et le samouraï. La politique française de la technologie. Paris: Economica.

Samuel, P. (1995). Remarques de bon sens sur la voiture électrique. Quels Carburants pour l'Automobile? Les Amis de la Terre, Etudes et Documents.

Schipper, L. (1995). Determinants of Automobile Use and Energy Consumption in OECD Countries. Annual Review of Energy and Environment, 20, 325-386.

Schmidt, V.A. (1996). The Decline of Traditional State Dirigisme in France: The Transformation of Political Economic Policies and Policymaking Processes. Governance, 9, 375-405, October.

Schreurs, M.A. (2003). Divergent paths: environmental policy in Germany, the United States and Japan. Environment, 45, 8-17, October.

Scott, A.J. (1995). The electric vehicle industry and local economic development. Environment and Planning A., 27, 863-875.

Segal, H.P. (1994). Future Imperfect: The Mixed Blessings of Technology in America. Amherst, MA: University of Massachusetts Press.

Shaheen, S.A., \& Meyn, M.M. (2002). Shared-Use Vehicle Services: A Survey of North American Market Developments. ITS World Congress Proceedings, Chicago, October 12.

Shnayerson, M. (1996). The Car that Could: The Inside Story of GM's Revolutionary Electric Vehicle, New York: Random House.

Shonfield, A. (1965). Modern Capitalism: The Changing Balance of Public and Private Power. New York: Oxford University Press.

Shrank, D., \& Lomax, T. (2002). 2002 Urban Mobility Study. Texas Transportation Institute.

Sierra Research. (1994). The Cost-Effectiveness of Further Regulating Mobile Source Emissions. February 28, Report No. SR94-02-04, Sacramento, CA.

Socolow, R., \& Thomas, V. (1997). The Industrial Ecology of Lead and Electric Vehicles. Journal of Industrial Ecology, 1, 13-36.

South Coast Air Quality Management District (SCAQMD, 2003). Historic Ozone Air Quality Trends.

Sperling, D. (1995). Future Drive: Electric Vehicles and Sustainable Transportation, Washington, D.C.: Island Press.

Sperling, D. (2002). Updating Automotive Research. Issues in Science and Technology, 18, 85-89.

Szarka, J. (2002). The Shaping of Environmental Policy in France. New York and Oxford: Berghahn.

Taylor III, A. (1993). Why Electric Cars Make No Sense. Fortune, July, 26, 126-127.

Touraine, A., Hegedus, Z., \& Wieviorka, M. (1980). La Prophétie Anti-nucléaire. Paris: Seuil.

Union Routière de France. (URF, 1998). Data on http://www.urf.asso.fr/essentiel/chiffref.htm\#3, on May 26.

United States Court of Appeals, Association of International Automobile Manufacturers, INC, DaimlerChrysler Corp. ..v. Commissioner MA DEP. 2002. No. 98-1036. 
U.S. Census Bureau. (2005). Statistical Abstract of the United States 2004-2005. Washington, DC: Claitors Publishing Division.

U.S. Federal Highway Administration (FHWA, 2003). National Transportation Statistics 2003, Washington, DC.

U.S. General Accounting Office (GAO, 1994). Electric Vehicles: Likely Consequences of U.S. and other Nations' Programs and Policies. December.

Van Warden, F. (1995). Persistence of national policy styles: A study of their institutional foundations. In B. Unger and F. van Waarden (Eds.), Convergence or Diversity? Aldershot, UK: Avebury.

Vogel, D. (1986). National Styles of Regulation: Environmental Policy in Great Britain and the United States. Ithaca, NY: Cornell University Press.

Vogel, D. (2003). The Hare and Tortoise Revisited: The New Politics of Consumer and Environmental Regulation in Europe. British Journal of Political Science, 33, 557-580.

Weber, M., \& Hoogma, R. (1998). Beyond National and Technological Styles of Innovation Diffusion: A Dynamic Perspective on Cases from the Energy and Transport Sectors. Technology Analysis \& Strategic Management, 10, 545-566.

Wilson, G.K. (1985). The Politics of Safety and Health. Oxford: Clarendon Press.

Woodruff, D. (1994). Electric Cars. Will They Work? And Who Will Buy Them? Business Week, May 30, 104-110.

Wouk, V. (1976). An experimental ICE/battery electric hybrid with low emissions and low fuel consumption capability. Society of Automotive Engineers, Detroit: Michigan.

Wouk, V. (1995). Hybrids: Then and Now. IEEE Spectrum, 32, 16-21.

\section{Interviews}

Becker, D. (1998). Telephone interview, July 29. Daniel Becker is director of Sierra Club's Global Warming and Energy Program.

Cackette, T. (2003). Personal Communication, May 14. Tom Cackette is Chief Deputy Executive Officer at CARB.

Comby, B. (2002). Telephone interview, April 3. Bruno Comby is the president of L'Association des Ecologistes Pour le Nucléaire.

Cornu, J. (1998). Telephone interview, May 29. J.P Cornu is director of Saft's electric vehicle unit.

Eley, K. (2005). Personal communication, October 4. Krista Eley is a policy analyst with CARB.

Geraghty, A. (1998). Telephone interview, June 21. Anne Geraghty is a former Manager of the Transportation Strategies Group at CARB.

Godinot, S. (2001). Telephone interview, January 24. Sylvan Godinot is a policy analyst with Réseau Action Climat France.

Lepage C. (2003). Telephone interview, March 2. Corinne Lepage was French Minister of the Environment between 1995 and 1998.

Lefetey, B. (2001). Telephone interview, February 12. Ben Lefetey is president of Amis de La Terre (French branch of Friends of the Earth) France.

Parent, M. (2000). Telephone interview, 12 June Michel Parent is a scientist at the Institut National de Recherche en Informatique et Automatique (INRIA).

Parvilliers, O. (1998). Telephone interview, May 29. Olivier Parvilliers is an analyst with Les Amis de la Terre. - France.

Prince, G. (2003). Telephone interview February 20. Gerard Prince is a policy analyst with Le Mouvement National Lutte pour Environnement.

Rebelle, B. (2001). Telephone interview, February 12. Bruno Rebelle is president of Greenpeace France.

Sato, N. (2001). Personal communication, January 24. Noburu Sato is an advanced-battery researcher with Honda.

Stephane, J. (2000). Telephone interview, November 1. Jean Stephane is a policy analyst with WWF-France. Toyota France. (2005). Personal communication, August 29. 